\title{
TECHNOLOGY USED BY FIELD MANAGERS FOR PINK BOLLWORM ERADICATION WITH ITS SUCCESSFUL OUTCOME IN THE UNITED STATES AND MEXICO
}

\author{
R. T. STATEN ${ }^{1}$ AND M. L. WALTERS ${ }^{2}$ \\ ${ }^{1}$ Center for Plant Health Science and Technology (CPHST), Animal and Plant \\ Health Inspection Service (APHIS), United States Department of Agriculture \\ (USDA), Phoenix, Arizona, USA \\ Retired,Programme Consultant; azbugdoc@cox.net \\ ${ }^{2}$ CPHST-USDA-APHIS, Deceased
}

\begin{abstract}
SUMMARY
Pink bollworm, Pectinophora gossypiella (Saunders), has been eradicated over a 7-state area in northern Mexico and the southern USA. Over this region, pink bollworm has been a key pest of cotton for $50+$ years. The bi-national eradication programme grew out of a long-standing Sterile Insect Technique (SIT) containment/exclusion programme to protect cotton in the San Joaquin Valley of California, as well as numerous area-wide research and demonstration projects in southern California, Baja California, and Arizona. It included all contiguous infested production areas of the states of Chihuahua, Sonora, and Baja California in Mexico. It also included all contiguous generally infested areas of the states of Texas, New Mexico, Arizona, and California in the USA. In this chapter we provide descriptions and key references for the technologies that were integrated in this multi-tactic, area-wide programme over its extensive geographic range. Technology described and used includes state programme-based central data management. The programme covered all activities including extensive GPS mapping, pheromone trap monitoring for adult populations, and the integration of all control operations. Operational information and data were shared among all participants as needed. Control tools included $B t$-cotton, the release of sterile moths, pheromone mating disruption, cultural control, and on a very limited basis conventional insecticide application. Critical area-wide resistance management using sterile moth release, rather than planting susceptible cotton in refugia, was pioneered in this programme. Success as documented was possible over an enormous and diverse cotton production area because the technologies used were heavily researched, broad-based, and could be tailored to fit each major area. Uniform management within each state was coordinated bi-nationally. This programme was conducted sequentially over time. Summaries for each state provide measurements of progress, success, and experiences gained through time of operation.
\end{abstract}

Key Words: Pectinophora gossypiella, pink bollworm trap, area-wide management, integrated pest management, Bt-cotton, resistance management, gossyplure, mating disruption, Sterile Insect Technique, SIT, pest detection survey, okra

J. Hendrichs, R. Pereira and M. J. B. Vreysen (eds.), Area-Wide Integrated Pest Management: Development and Field Application, pp. 51-92. CRC Press, Boca Raton, Florida, USA.

(C) 2021 U. S. Government 


\section{INTRODUCTION}

Introduction of the pink bollworm (PBW), Pectinophora gossypiella (Saunders), to the south-western USA and north-western Mexico irrigated cotton growing regions was first reported in 1916 near Torreón, in Coahuila, Mexico (Noble 1969). This infestation was presumed to originate from seed shipments from Egypt into Mexico in 1911. It quickly became the key pest of cotton.

With the exception of the San Joaquin Valley of California, no other pest species was as dominant or detrimental to the fortunes and survivability of the cotton farmers of these regions. This was particularly true in the cotton growing areas of the Colorado River Basin. Insecticide use for this pest was extensive for a period of more than 45 years.

Early attempts at management or eradication with conventional insecticides were expensive and difficult. All control efforts resulted in some short-term success and frequent frustration. This was true both when control was on a field-by-field basis and also in the case of a coordinated, insecticide-driven state-wide programme in Arizona (Anonymous 1961; Schmitt Jr. 1967).

The emphasis of this chapter will be to record the technology used and the success of the bi-national Pink Bollworm Eradication Programme to assist others in the development of bio-rational approaches to the pest. We expect such knowledge will be critical in mitigating any seed-borne movement of PBW back to the USA and northern Mexico. The programme herein described evolved only after in-depth research (over 3000 references in a CPHST-APHIS-USDA data base and Naranjo et al. 2002) and numerous large-scale field trials. All this investment in R\&D is frequently oversimplified and overlooked when the positive results of the programme are considered.

The programme operations started on a sequential basis in the generally infested areas of the south-western USA and northern Mexico (Fig. 1). This "rolling carpet" approach (Hendrichs et al. 2021), followed as programme phases, was necessary due to the physical limitations of the production output of sterile PBW moths by a single mass-rearing facility located in Phoenix, Arizona.

In this summation we identify the most important tools commonly used by the programme and provide relevant references and accounts of experience used in the design of the programme. Important summary data utilized to measure programme progress are also provided. Units of measurement were those used in the respective countries (metric system in Mexico, "U.S. customary unit system" in the USA). The data came from the records used in day-to-day management and are provided in Sections on a state-by-state basis in both countries. 
Each of these Sections starts with a listing of the state managers who were responsible for day-to-day operations and ultimately were the backbone of the programme's achievement. The success of this programme grew out of a longstanding containment/exclusion programme in the San Joaquin Valley of California (Staten et al. 1993) and numerous area-wide research and demonstration projects in geographically-defined locations particularly in southern California, Baja California, and Arizona (Walters et al. 2000). Many of these trials were reported through proceedings of the National Cotton Council Beltwide Cotton Production Conferences.

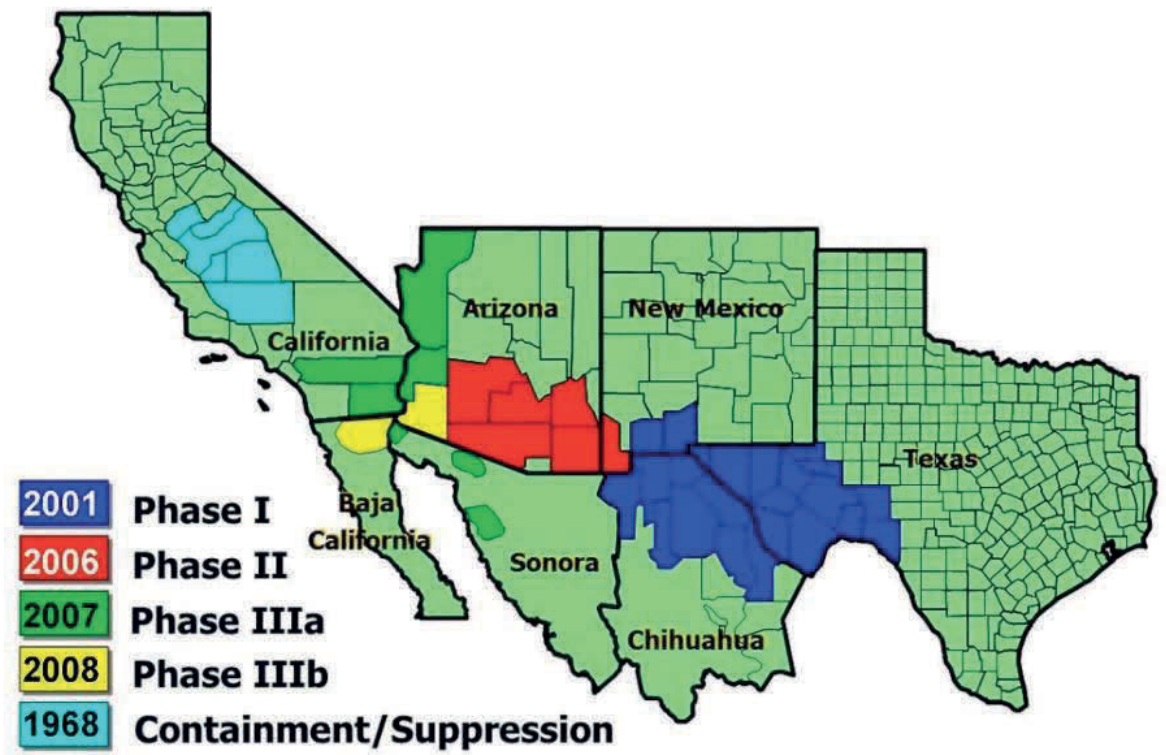

Figure 1. Pink bollworm eradication phases, dates, and areas in south-western USA and north-western Mexico (updated from Grefenstette et al. 2009).

\section{MANAGEMENT}

Standardized management and organization are critical in integrated area-wide insect pest eradication programmes (Vreysen et al. 2007; Suckling et al. 2014). As this was not a "voluntary" programme, all in-season applications of suppression treatments (insecticides, sterile insect release, and pheromones) for PBW were under a central management and coordinating authority in each state. This area-wide concept of the bi-national programme had to be agreed upon by the majority of all cotton growers in referenda held before the programme could be initiated in each of the states. In Arizona, for example, the programme could only be started after a second grower referendum passed in 2005 with more than a $66 \%$ grower approval (Grefenstette et al. 2009). 
A brief outline of management entities in the USA and Mexico involved in the PBW eradication programme are shown in Tables 1 and 2.

Table 1. Brief outline of management entities involved in the USA and their contributions to the pink bollworm eradication programme

\begin{tabular}{|c|l|}
\hline \multicolumn{1}{|c|}{ ENTITIES IN USA } & \multicolumn{1}{|c|}{ CONTRIBUTIONS } \\
\hline USDA-APHIS & $\begin{array}{l}\text { All sterile insect production, USA release cost, and } \\
\text { USA regulatory enforcement }\end{array}$ \\
\hline $\begin{array}{l}\text { Within-state cost of all non-SIT }{ }^{2} \text { in-field treatments } \\
\text { and operations (includes Bt-cotton, pheromone } \\
\text { mating disruption, and insecticides) }\end{array}$ \\
\hline $\begin{array}{l}\text { 1. Texas Boll Weevil Foundation } \\
\text { (TBWF) }{ }^{1}\end{array}$ & $\begin{array}{l}\text { All field management of treatments, monitoring, } \\
\text { evaluation and reporting }\end{array}$ \\
\hline $\begin{array}{l}\text { 2. New Mexico PBW and BW } \\
\text { Foundation }{ }^{1}\end{array}$ & $\begin{array}{l}\text { All field management of treatments, monitoring, } \\
\text { evaluation and reporting }\end{array}$ \\
\hline $\begin{array}{l}\text { 3. Arizona Cotton Research and } \\
\text { Protection Council (ACRPC) }\end{array}$ & $\begin{array}{l}\text { All field management of treatments, monitoring, } \\
\text { evaluation and reporting }\end{array}$ \\
\hline $\begin{array}{l}\text { 4. California Cotton Pest Control Board } \\
\text { (CCPCB), funds managed by } \\
\text { CDFA }{ }^{1}\end{array}$ & $\begin{array}{l}\text { All field management of treatments, monitoring, } \\
\text { evaluation and reporting }\end{array}$ \\
\hline
\end{tabular}

${ }^{1}$ All funds were raised via local assessments through organizations 1-4, and from legislative support to USDA via the National Cotton Council

${ }^{2}$ SIT $=$ Sterile Insect Technique

\section{TECHNOLOGY USED}

The successful PBW eradication was dependent on a multi-tactic approach in which the authors will not designate one control technology as most critical for its success. All technologies, integrated in different ways in the different areas, were essential and born from in-depth research and development efforts over a 100-year time frame (.

This programme was fortunate in following an ongoing Boll Weevil Eradication Programme (Knipling 1971; Allen 2008), which established the benefits of a standardized area-wide approach to programme success. Lessons learned and organizational basics were of extreme importance. El-Lissy et al. (2002) used a simple classification for all programme activities. This paper was the foundation for all field operations used by state organizations for PBW.

All activities were sub-divided into three activities: 1. mapping and data management, 2. surveying (trapping and larval sampling), and 3. control. The authors will generally follow these three critical components, adding detail to each to fully elucidate their scope and interaction. It should be noted that a separate Section is included dedicated to transgenic cotton. Despite being an essential part of the programme's control components, unique issues related to the incorporation of transgenic cotton require additional discussion. 
Table 2. Brief outline of management entities involved in Mexico and their contributions to the pink bollworm eradication programme

\begin{tabular}{|c|c|}
\hline ENTITIES IN MEXICO & CONTRIBUTIONS \\
\hline $\begin{array}{l}\text { SAGARPA (Ministry of Agriculture, } \\
\text { Livestock, Rural Development, Fisheries } \\
\text { and Food), SENASICA (National Service of } \\
\text { Health, Food Safety, and Agriculture } \\
\text { Quality) }\end{array}$ & $\begin{array}{l}\text { Leadership, Technical and managerial support, } \\
\text { critical funds (varied year to year dependent on } \\
\text { needs and availability at national level) }\end{array}$ \\
\hline $\begin{array}{l}\text { USDA-APHIS-International Services and } \\
\text { Plant Protection and Quarantine (PPQ) }\end{array}$ & $\begin{array}{l}\text { Technical and information technology support, } \\
\text { logistical support, bi-national coordination, } \\
\text { coordination with USA embassy for security, } \\
\text { procurement of some supplies, and some field } \\
\text { personnel and } \mathrm{SIT}^{2} \text { coordination }\end{array}$ \\
\hline $\begin{array}{l}\text { 1. Comité Estatal de Sanidad Vegetal (state } \\
\text { plant protection committee) de } \\
\text { Chihuahua }^{1}\end{array}$ & $\begin{array}{l}\text { State level management of operations (treatment, } \\
\text { survey, and control), funding via grower } \\
\text { assessments and direct contributions }\end{array}$ \\
\hline $\begin{array}{l}\text { 2. Comité Estatal de Sanidad Vegetal (state } \\
\text { plant protection committee) de Sonora }{ }^{1}\end{array}$ & $\begin{array}{l}\text { State level management of operations (treatment, } \\
\text { survey, and control), funding via grower } \\
\text { assessments and direct contributions }\end{array}$ \\
\hline $\begin{array}{l}\text { 3. Comité Estatal de Sanidad Vegetal (state } \\
\text { plant protection committee) de Baja } \\
\text { California }^{1}\end{array}$ & $\begin{array}{l}\text { State level management of operations (treatment, } \\
\text { survey, and control), funding via grower } \\
\text { assessments and direct contributions }\end{array}$ \\
\hline
\end{tabular}

${ }^{1}$ Authors were not involved in funding decisions, but they understand that sources of revenue varied according to available resources from the various entities in the different states

\subsection{Mapping and Data Management}

Eradication requires complete control of needed technology over broad or welldefined geographic areas, over which uniform management is of paramount importance. This starts at the beginning of each growing season with the process of finding and mapping of all fields with cotton. Each state's programme had to be able to monitor all these fields. Managers required rapid access to all mapping, survey and treatment data. PBW populations are clustered and non-uniform in distribution within a field and within subsites and definable geographic areas. Management must be able to operate within a spatial context allocating resources where they are most critically needed without regard to ownership or political constraints.

When Texas initiated the first surveys of PBW populations, it modified its boll weevil data management system to include all PBW management needs. This was then made available to all participating states. Details of how this data management system is used today can be found under TBWEF (2019). It was adopted by all state programmes except California, which already had a long-standing data management system in place. 
Within the above context each state management had complete access to its mapping and data including the following:

1. Precise GPS locations of all fields with unique identification numbers for every field and its trap or traps

2. Barcoded identification of all traps with GPS location within the programme

3. Storage and access to all trap and capture data for sterile and non-sterile specimens

4. Precise location of all $B t$ and non-Bt cotton (Gossypium hirsutum L.) fields, including a distinction for Pima cotton, Gossypium barbadense L.

5. Access to detailed information on all programme-applied pheromone mating disruption treatments, conventional insecticides, and sterile moth releases - this included access to needed regulatory notifications within each state and flight recordings for all spray and sterile release aircraft, and

6. Reports generated from complete data by servicing date or any other needed time interval and geographically-defined parameter.

The use of this harmonized system expedited communication within and between state programmes.

\subsection{Survey Technology}

\subsubsection{Trap Selection and Use}

The eradication of PBW has long relied on the use of the delta trap for surveys. This trap and the modified Frick trap it replaced are fully illustrated by Foster et al. (1977). The trap is deltoid in shape and is 7 inches $(17.8 \mathrm{~cm})$ long and 3.5 inches $(8.9 \mathrm{~cm})$ on each of its three sides. The inverted triangular opening found on each end is one inch $(2.54 \mathrm{~cm})$ on each of the three sides that form the opening.

The delta trap was first used on an area-wide basis in the San Joaquin valley of California in 1976. Staten et al. (1993) reported on multiple years of data from very large numbers of this trap in over one million acres (>400 $000 \mathrm{ha})$ of cotton each year. The delta trap will overload in high PBW populations when traps quickly exceed 50 moths per service interval. It is however the most sensitive trap known to the authors in detection and monitoring of lower density PBW populations. The most important need in this programme was its ability to successfully find low level populations before they reached levels only allowed in pre-eradication pest management scenarios.

The following are four key requirements of traps needed for operational success:

1. Superiority as a detection tool with the best capture rate in low population densities

2. The trap must facilitate accurate identification, preserving the specimen intact enough for dissection and/or, with special servicing, DNA analysis

3. The trap must be durable enough to withstand "normal" extremes such as wind, rain, handling and routine field and operational hazards, and

4. The trap must be cost- and operationally-effective to use. This includes unit cost, storage, installation, recovery, and replacement. 
Throughout the PBW programme, trap density standards were set at one trap per 80 acres (32.4 ha) in the USA and one trap per 20 ha in Mexico for all Bt-cotton (cotton genetically modified to express the endotoxins of Bacillus thuringiensis Berliner) (Bt). All cotton fields which did not express these resistant traits were trapped at one trap per 10 acres (4.05 ha) in the USA or one trap per 4 ha in Mexico. Trap placement at these numbers required 2 considerations. The trap must be in a position from which its emitted pheromone attractant would have a high probability of intersecting the casting flights of the male moths. It must also be reachable by servicing personnel quickly and efficiently.

Studies by Leggett et al. (1994) resolved many questions involved in management of trapping. Traps were placed on field margins preferably where they will not be destroyed in normal field cultivation activities. Trappers are trained to look at such factors as prevailing air movement patterns as fields cool down after sunset. Male moths typically become active in search of females as temperatures decline with an $80^{\circ} \mathrm{F}\left(26.7^{\circ} \mathrm{C}\right)$ threshold (Lingren1989). Traps were serviced or changed at least weekly.

\subsubsection{Trap Lure Formulation}

The discovery and development of the female sex attractant of the PBW was the single most important entomological breakthrough of the mid 1970's with respect to PBW control. The name "gossyplure" and its characteristics were first published by Hummel et al. in 1973. Bierl et al. (1974) published detailed data illustrating its importance and the role of its specific components. Gossyplure is a near 50/50 ratio mixture of (ZZ) and (ZE)-7,11 hexadecadien-1-ol acetate isomers. This paper also noted the detrimental effect of the EE and EZ isomers of this molecule in reducing attraction. The introduction of a controlled release formulation of gossyplure had a profound impact on the San Joaquin Valley exclusion programme being implemented at that time for PBW in California. Previous adult surveys had relied on the parapheromone hexalure. Hexalure required 20+ times the attractant for much lower capture rates and detection efficacy.

A number of controlled release formulations have been used in PBW traps. Flint et al. (1974) provided the first published paper showing the advantages of a controlled release trap lure formulation for PBW. Flint used the red rubber septa and a version of this lure was used throughout the programme at $4 \mathrm{mg}$ per lure. There are other formulations which have a flatter emission release rate over longer periods of time, but they are more expensive.

Throughout the eradication programme covered in this publication, lures were replaced with every trap service or at least every two weeks, even though the septa have excellent properties for a longer period. This lure is currently produced for all state programmes at cost by the Arizona programme.

The quality of the gossyplure is as or more important than the substrate used. Staten et al. (1988) illustrated the importance of using trap bioassays in the procurement of gossyplure for surveys. Important differences of PBW attraction still cannot be explained with known chemical analysis alone; traces of an alcohol are suspected. The programme in Arizona maintains a supply of "technical" grade gossyplure for all post-eradication survey in this programme. 


\subsubsection{Moth Identification}

The programme had to face two critical issues, namely species identification (taxonomic) and separation of sterile from native insect specimens. From the first sterile moth releases in the San Joaquin Valley in 1968, moth taxonomic identification used labial palp bands, and genital clasper characteristics to separate $P$. gossypiella males from other species. The survey traps and lures used, with rare exceptions, only attracts the male moth. The trap is not absolutely species-specific and will sometimes capture a few accidental "contaminant" specimens. Most of these do not resemble PBW. There are a few similar-sized moths which may have an attractant similar to gossyplure. If these captures were confused with PBW, they could affect treatment decisions adversely. Good dissection techniques and microscopic examination were used for specimen identification. This was considered sufficient throughout the years of the programme. Late in the programme, DNA signatures were under development at the University of Arizona.

Separation of mass-produced release moths from native moths in the cotton fields was accomplished using a dye incorporated in the sterile moth larval production diet. Calco Red oil food dye was used as a diet induced marker (Graham and Mangum 1971). Marking was very accurate as non-marked moths could not be found among laboratory-produced moths even when extreme searches were conducted periodically throughout the Phoenix rearing facility's history. Searches involved thousands of aged moths crushed on white filter paper. In these searches, moths were routinely taken from discarded egg production cages. This, however, cannot completely represent moths under field conditions.

A simple paper chromatograph technique was in use in support of sterile moth releases as early as 1970 in the Coachella Valley of California, when the first author worked with that trial programme. It has endured through all sterile moth releases. The technique involves the use of a small straight sided vial at or near $25 \times 10 \mathrm{~mm}$; exact size is not critical. A moth is crushed in the bottom with an uncontaminated rod, preferably glass. The vial plus moth then receives $1 \mathrm{ml}$ of hexane and a strip of chromatographic paper cut to $9 \times 30 \mathrm{~mm}$. The strip is cut to a point at its terminal end so that as the solvent moves upward it concentrates the dye in the tip as it dries, facilitating identification.

As the eradication programme reached completion, the potential for misidentification became extremely critical. As each state programme reached this point, the importance of absolute accuracy increased. If a 1:1000 000 rate of error was possible, a second independent marker or analysis with high levels of confidence would, in terms of probability, make a missed detection of a non-marked sterile virtually impossible.

Burns et al. (1983a) used an inductively coupled plasma-atomic emission spectrometer to test possible use of 13 elemental markers. Out of those, Strontium (Sr) proved to be the most viable candidate as a second marker, independent from the Calco Red dye. Burns also illustrated its potential in sterile Mediterranean fruit fly Ceratitis capitata (Wiedemann) analysis (Burns et al. 1983b).

PBW larval diet preparation had undergone major changes in the mass-rearing facility (Miller et al. 1996), so some re-testing with Sr was required. In this effort in 2011, a 540-ppm level of Sr was found to have excellent retention in moths as old as 
45 days (Walters, unpublished reports). This technology was used starting in 2012 for all the sterile moth production.

\subsubsection{Larval Sampling}

Pre-eradication pest management scouting procedures usually used larval PBW populations at $2-5 \%$ as the action threshold to trigger insecticide ground and aerial applications of conventional insecticides. When populations reached this level, nonselective insecticides were considered the only workable solution. All treatment decisions were on a field-by-field basis. In many areas that resulted in frequent (5-15) treatments for PBW alone or in combination with insecticides for other pests in a growing season.

In the case of the PBW eradication programme, protocols used for suppression were designed to prevent development of populations high enough for normal detection of larvae. Boll larval sampling was used most extensively in the first 2-3 years of the programme. Some states used a random selection of non- $B t$ fields for boll collection to assess larval populations. Conversely, during the first years of the Arizona programme all non- $B t$ fields were sampled. This was logistically possible due to a high ratio of $B t$ to non- $B t$ fields. In instances where pockets of higher native moths were detected in cotton fields, targeted searches were also used as the programme progressed.

Two different sampling methods were used. Bolls collected from the field could be processed within boll holding boxes (Fye 1976) or by direct examination of bolls cut open immediately after field collection. When the data are needed for immediate operational decisions, boll cutting is critical. In this case data could trigger an immediate conventional insecticide treatment. This became extremely rare as the programme progressed. For resistance monitoring, or when some assessment of reproduction was desired, boll boxes were used. The detection threshold of a trap is always better than any larval assessment.

\subsection{Control Technologies}

Throughout the eradication programme, PBW control was the responsibility of statewide programme management (Tables 1 and 2). These organizations controlled all treatment activity except for the type of cotton to be grown. Producers chose not to plant or to plant $B t$-cotton, although the latter option was encouraged. Individual growers were responsible for adhering to Environmental Protection Agency (USEPA) regulations in terms of respecting seed contracts and label compliance. In Texas, USA and Chihuahua, Mexico (Phase I), the PBW programme ran simultaneously with active boll weevil eradication, where boll weevil treatments were concurrent. In the USA, the grower who chose to use $B t$-cotton contracted with the seed provider to pay the technology fee for that resistant cotton. Where $B t$-cotton was not in use, producers paid a higher assessment for programme-applied pheromone mating disruption and other control actions needed for suppression. Base costs covered other programme aspects. 


\subsubsection{Transgenic Cotton}

Cotton genetically modified with genes from $B$. thuringiensis $(B t)$ provided the single most important change in PBW control in the late $20^{\text {th }}$ century. In 1990, Wilson et al. (1992) conducted the first tests of experimental lines "that carry an altered version of the insect-controlling protein gene from B. thuringiensis kurstaki". These lines were not commercially available at that time. The technology subsequently developed to a commercial state quickly.

The PBW mortality levels which commercial Bt-cotton varieties produced were unprecedented at $>99 \%$ (Flint et al. 1995; Watson 1995). Staten et al. (1995) noted its potential importance as an eradication tool, proposing its integration with other "soft" technologies because it targeted only the larval stage as it fed within or on the plant. Because $B t$-cotton varieties did not affect adult PBW it would, in effect, provide an excellent synergistic tool when combined with the inverse density-dependent action mode of the SIT and mating disruption.

The immediate concern for the $B t$ technology in all control contexts, however, was that its extreme efficacy would lead to overuse and thus ultimately to resistance development. This has proven to be a realistic concern. Tabashnik et al. (2013) offered an excellent review "after the $1^{\text {st }}$ billion acres of use". Resistance to both common endotoxins ( $C r y$ 1 $A b$ and $C r y$ 2Ac) found in commercial cotton resulted in major losses or shifts in strategies in India and China (Tabashnik et al. 2013; Wan et al. 2017).

Currently there is discussion of major losses in Bt-cotton from PBW in Pakistan (Shahid 2014). Losses from resistant PBW have been reversed by using hybrid cotton in China (Wan et al. 2017). In this case $\pm 25 \%$ of all cotton plants would not express the $B t$ traits. This provides "in the bag refugia" as described by Head and Greenplate (2012).

Within the eradication zones, the commercial use of $B t$-cotton always had label restrictions requiring resistance management by providing plantings of susceptible cotton (refugia). These enforced EPA label restrictions required that an individual grower entity use one of two choices. The grower could plant at least $20 \%$ of his cotton with a non- $B t$ variety, which could be treated with any labelled conventional insecticide. Alternatively, the $2^{\text {nd }}$ choice was that at least $5 \%$ of the surface would be of a susceptible variety of cotton, but the grower could not use a long list of conventional insecticides on those refugia.

Additional restrictions published in 2005 for the 2006 growing season added mating disruption and sterile moth release to this list. These restrictions in the use of $B t$-cotton precluded eradication. Under this scenario, simple calculations could place production of a diapausing PBW population in a 5-acre field at $>500000$ insects in one late-season generation. This is a very conservative number. Late-season cotton produces susceptible bolls for more than one generation, thereby laying the groundwork for a large overwintering population. 
Staten et al. (1999) had noted the potential use of sterile moth release over Btcotton in lieu of structured untreated refugia as part of a resistance management strategy. Sterile insect distribution is more reliable than non-directed capricious movement found in nature from native populations which are non-randomly distributed.

Arizona immediately sought a section $24 \mathrm{C}$ special local needs label to utilize a grower choice of up to $100 \%$ Bt-cotton as long as this acreage would receive an average of 10 or more sterile insects/acre/day (24.7/ha/day). This application ultimately required an extensive formal review before an EPA Science Advisory Panel in 2006 (Antilla and Liesner 2008). This strategy with some variation is in use today. Tabashnik et al. (2010) published an excellent review and assessment of this strategy in Arizona.

The choice of what cotton is to be grown has always been left to the individual producer in this programme. As part of the field mapping procedures all growers are canvassed in early spring for an inventory of expected fields to be planted. The inventory includes a separation of $B t$ and non- $B t$ types. All fields are then checked and tested with an ELISA test after germination (AGDIA Inc. Elkhart, Indiana, USA), as a safety check to ensure accuracy of Bt-cotton distribution maps.

\subsubsection{Mating Disruption}

Within this eradication programme, mating disruption was used on all non-Bt cotton during at least the first four years of each state's operations. The hand-applied PBW Rope (Shin-Etsu Chemical Company) was preferred. Aerially applied NoMate Fiber, NoMate Mec (Scentry Biologicals) and Check Mate (Suterra), were also used when circumstances required. These latter formulations had an effective disruption time of 8 to 14 days. A review with product details is found in Staten et al. (1997). The use of gossyplure for mating disruption for PBW represents the most successful early application of this technology (Cardé et al. 1997; Cardé, this volume). A hollow fibrecontrolled release formulation was the first EPA registered disruptant (Brooks et al. 1979).

The use of pheromones for mating disruption is fundamentally different than any conventionally applied insecticide (Cardé, this volume). A treatment of a controlled release pheromone does not kill the intended target. In the case of PBW, treating an already reproducing or mated population in even moderate levels is therefore futile. There was an "attract and kill" system (Staten and Conley patent 4671010 now expired), which involved adding very small traces of a pyrethroid insecticide to the adhesive in the NoMate fibre system. It appeared to be of assistance, but its value was not great.

Staten et al. (1997) characterized both low and high-rate systems. Low-rate systems (applicable by air) require frequent reapplication with escalated error potential as each treatment timing decision is made to achieve constant disruption for a 30 to 60-day time frame. The PBW eradication programme used in the aerial spraying the three low-rate formulations described above. 
The first high-rate system known as PBW Rope (Flint et al. 1985) was field tested in the Imperial, USA and Mexicali, Mexico valleys in 1986 (Staten et al. 1987). This PBW Rope provided continuous disruption and efficacy over a much longer time frame than 4-8 applications of low-rate systems applied by air. This was true even on a field-by-field basis. From that time to the present, the formulation has only had one major change. Its application, when correctly done, maintains complete trap shutdown for a 50-70-day time frame in low to moderate populations.

PBW Rope was designed to be tied on an individual plant. The programme began to pre-wrap it on a bamboo stake in 2006 in Arizona (Antilla and Liesner 2008). The current formulation was applied at 200 /acre or $500 /$ ha. For maximum efficacy in upland cotton, it must be in the field at or before cotton reaches the 6-leaf stage. This is before a female can mate and live long enough to successfully oviposit. In rare cases a second application has been justified.

Area-wide (mandated) use of pheromone has a long history. Baker et al. 1990 reported on a one-year project in the Imperial Valley of California using low-rate systems. It covered $>40000$ acres and targeted the first two generations. Low rate pheromone systems were required before first square (first flower bud) formation. Its goal was to suppress PBW long enough to reduce conventional insecticide use and secondary whitefly problems.

The aforenoted review by Staten (1997) covered two separate, later area-wide trials. These trials were in the Coachella Valley of southern California and the Parker Valley of Arizona. The most important trial in Parker, Arizona is covered in detail over a 5-year period by Antilla et al. (1996). Both trials strongly illustrated the importance of an area-wide approach with pheromone disruption. For the first time, after the first or second year, season-long control without major reliance on conventional insecticides became possible. Results were obtained in an area where the pest was normally severe. These trials both depended partially or completely on the high-rate systems. Additional trials in the Imperial and Palo Verde Valleys were used to develop a better understanding of the SIT when combining the technologies (Staten et al. 1999; Walters et al. 1998, 1999, 2000).

\subsubsection{Sterile Insect Release}

Releases of sterile moths in this programme had two purposes: a suppression tactic in and of itself, and as a resistance prevention strategy (see discussion in Section 3.3.1.). The release of sterile PBW was started in 1968 in the San Joaquin Valley of California as part of a containment/exclusion strategy to prevent establishment of the pest (Staten et al. 1993, 1999). Releases were continuous in areas of detection from 1970 through 2011.

Over time three sterile moth rearing facilities were established to produce PBW for field release, namely a temporary facility in Harlingen, Texas (1968-1970) and two separate facilities in Phoenix, Arizona, from 1969-1995, and 1995 to the present. The current existing facility is unique in that it was designed to produce twice the known maximum needs of the then-existing San Joaquin Valley programme. 
The purchase of a 66000 square feet $\left(6131 \mathrm{~m}^{2}\right)$ building in Phoenix, its extensive renovation and most of its equipment were paid for by the CCPCB (through the California Department of Food and Agriculture (CDFA) and managed by Mr. Wally Shropshire as chairman from 1969 through 2010, and Mr. Ted Sheely, the current chairman).

The Phoenix mass-rearing facility has been managed by USDA with California funding and minimal federal (appropriated) funds until 2005. From 2005 onward it phased into a fully USDA federally funded operation, less a few expenses such as property taxes. The production and funding of sterile moths for release then became a USA government obligation. All other field costs remained with the grower community (Tables 1 and 2).

All moth handling, packaging, chilled shipment, handling pre-release, and release procedures were developed for the San Joaquin Valley containment/exclusion programme. This occurred long before eradication started in the fully infested areas. The reporting of the successful San Joaquin Valley programme is not complete, but segments and procedures are partially covered by Rudig and Keaveny (2008) and Staten et al. (1993). Many of the sub-areas of this valley have more favourable growing conditions for PBW population development than did areas which had moderate to heavy infestations. Examples include Safford, Arizona and the El Paso Valley of Texas. Wind-borne PBW movement into the San Joaquin Valley was documented and monitored by the CDFA programme. In addition, Stern and Sevacherian (1978) and Stern (1979) established its potential through monitoring of the desert between the San Joaquin Valley and with consideration of plant growth analysis and studies of the overwintering potential.

By 2005 the Phoenix mass-rearing facility had enough space, all major equipment needed, and the technology developed to produce an expected 20-28 million moths per day. Previously it had been producing an average of 5 million moths per day. Production for the years in which the "expanded" eradication programme was in effect is shown in Table 3. Range of production resulted from varied season lengths of the multiple treatment areas.

The sterile moths were directly collected after adult emergence from pupae with immediate chilling at $\pm 35^{\circ} \mathrm{F}\left(1.66^{\circ} \mathrm{C}\right)$. They were maintained at as near that temperature as possible through irradiation and packaging. Shipment occurred in specialized pre-chilled shipping containers to the release destinations. Any holding time of the sterile moths at destination was in cold rooms or cold boxes. They were then loaded into specialized aerial release machines installed in small aircraft (Pierce et al. 1995).

The release aircraft must be capable of working speeds of 120 miles $/ \mathrm{h}(193 \mathrm{~km} / \mathrm{h})$. A Cessna 206 aircraft served this purpose in this programme. Release height above the cotton fields was maintained at an average of 500 feet $(152 \mathrm{~m})$ above ground. Sterile moths were normally released within 24 hours post-collection. When insects were held an additional day, loss in quality was observed. Individual non- $B t$ fields were specifically targeted. Release grids were used for a lower release rate over $B t$ fields. 
Table 3. Daily sterile moths produced at the Phoenix Arizona mass-rearing facility (in millions) used for release in the bi-national PBW eradication programme areas

\begin{tabular}{|c|c|c|c|c|c|c|c|c|c|c|}
\hline Year & 2004 & 2005 & 2006 & 2007 & 2008 & 2009 & 2010 & 2011 & 2012 & 2013 \\
\hline $\begin{array}{l}\text { Production } \\
\text { goal/day }\end{array}$ & 5.0 & 10.0 & 22.0 & 22.0 & 22.0 & 26.0 & 20.0 & 20.0 & 14.5 & 5.0 \\
\hline Mean/day & 5.4 & 12.5 & 22.9 & 25.1 & 24.1 & 27.2 & 22.2 & 22.9 & 16.3 & 5.8 \\
\hline Range low & 6.8 & 1.3 & 16.2 & 19.6 & 10.2 & 19.6 & 20.2 & 20.3 & 14.7 & 4.1 \\
\hline Range high & 15.5 & 6.7 & 30.1 & 33.2 & 30.7 & 32.9 & 27.2 & 32 & 22.8 & 7.3 \\
\hline
\end{tabular}

\subsubsection{Conventional Insecticides}

Insecticides were those applied to kill the pest as a direct result of their application. This form of treatment was and is the only method available to manage a rapidly expanding population when larvae are first found in the cotton bolls. In many areas, before initiation of PBW eradication, this occurred early in the cotton fruiting cycle and lasted for 2-4 months.

In the case of the eradication programme, all other control activities started either at planting (Bt-cotton) or before a moth can be mated and lay its first fertile egg on a plant with a susceptible fruiting form. Optimum application of mating disruption was before the 6-leaf crop stage; sterile release started even before.

An indicator of success in the first few years of programme initiation was the reduction in insecticide sprays from those previously used by the producers individually. Choice of insecticide was made based on local recommendations and knowledge. The most commonly used insecticides were chlorpyrifos as Lockon or Lorsban (Dow Chemical), or a pyrethroid labelled for PBW control. As shown in the following outcome Section, very low percentage of the total area required any traditional insecticide treatment. That predominantly occurred in the first two years of programme operations. This approach was particularly applicable in Texas and New Mexico, before sterile moth release was available.

\subsubsection{Cultural Control}

Among the earliest research conducted on PBW involved cultural practices for its control (Noble 1969). As PBW exploded through Arizona, invading southern California in the 1960's and 1970's, cultural control became a major area of research (Naranjo et al. 2002). Over a 40-year period, each growing area within the generally infested cotton areas has developed a balance between profitable production and essential regulated cultural practices. 
PBW eradication used all existing regulations as a standard. Management encouraged or was involved in any needed regulatory enforcement of these best practices. Of greatest importance were the programme actions that were needed for post-harvest crop destruction and host-free periods to minimize carry-over between cotton crops.

\section{OUTCOMES}

The successful eradication programme outcome is presented on a state by state basis in the general order that the seven states initiated their activities as part of the programme phases (Fig. 1).

Management credits herein provided for each state are for those managers who were responsible for day-to-day decisions, operation, all data acquisition and evaluation. Managers listed were accountable for day-to-day success as well as setbacks. These individuals are considered as the most important contact points in each state. The first listed are those in the operational offices where daily decisions were made.

The programme was feasible because only non- $B t$ cotton areas required centralised control cost and intensive day-to-day attention. We provide total cotton area planted and percent $B t$-cotton to partially illustrate the magnitude and intensity of operations in each of the states. States and cotton areas within the states with the highest ratios of non- $B t$ required the most intense management per acre or ha. The data presented are in units of measurement found in the respective field records (acres or ha).

First programmatic treatments occurred in Texas in 2001. Overall, the last PBW detected as adult unmarked moths were captured in 2012. The last sterile release treatments occurred in 2013. Population collapse is illustrated by annual adult native moth capture.

An understanding of positive economic impact is found in the reduction and eventually elimination of any detectable larvae. Direct cost-benefit is best illustrated by the decreasing use of annual inputs in high-rate pheromone (PBW Rope), sprayable pheromone systems, and conventionally applied insecticides. Lessons learned from the first state to start were extremely beneficial as the subsequent states entered the programme.

\subsection{Texas, USA (Phase I)}

Edward Herrera, Supervisor, El Paso /Trans-Pecos District, 1999-2013

Osama El-Lissy, TBWF Programme Director, 1999- 2000

Charles Allen, TBWF Programme Director, 2001-2009

Larry Smith, TBWF Programme Director, 2009-present

The El Paso / Trans-Pecos growers of western Texas were the first group to initiate the PBW suppression and eradication efforts reported here. The Texas Boll Weevil Foundation (TBWF) was, in 1999, fully functional and successfully involved in its part of a USA cotton belt-wide eradication effort for boll weevil, Anthonomus grandis 
Boheman (Allen 2008). Recently detected weevil populations had become a major concern in western Texas, and treatment was restricted to these populations in 1999 through 2005 in this area.

In 1999, the grower community of western Texas passed a referendum to join the TBWF for boll weevil eradication and to initiate PBW population evaluation. In 2001, the PBW area-wide suppression activities were added to eliminate economic loss from PBW for the growers in the area. Details and complete results for the first years are covered by Allen et al. (2005). Control activities began in 2001 without sterile releases and in the absence of isolation. The programme was modelled after the Arizona Parker project (Antilla et al. 1996).

The Texas PBW programme encompassed two distinct agronomic areas (Fig. 1). The El Paso "Valley" in the USA is separated only by the Rio Grande (Bravo) River from the Juárez "Valley" of Mexico. Mexico did not start programme activities the same year (2001) despite the fact that, in many cases, fields from the two countries were less than 200 meters apart. More than half of the Texas programme was in this valley.

Cotton in the El Paso work unit was more than 50\% Pima (G. barbadense). This species of cotton is considered to be the most PBW susceptible commercial cotton grown as it was all non-Bt. Initial PBW populations were very high as depicted in trap counts in the year 2000 (Table 4). Due to lack of isolation, population suppression and economic loss prevention were the only achievable goals for the first two years of the Texas programme (2001-2002).

In contrast, the area east of El Paso comprised a distinctly different production system. This included the general vicinity of the Pecos River and the town of Fort Stockton, Texas. Land was characterized by a shorter season and high usage of Btcotton. In this distinctively different area, Pima production was minimal, being grown principally in one isolated organic cotton block. Fields in this zone were dispersed over a very large geographic area and occurred in isolated clusters. Separation of such cotton blocks was frequently more than 50 miles.

From 2001-2004 (Table 4), programme treatment options on non-Bt cotton were limited. Required treatments were heavily concentrated in the El Paso Valley area. Aerially applied NoMate fibre, with $0.000586 \mathrm{lb}(0.265 \mathrm{~g})$ pyrethroid per acre mixed in the adhesive as an "attract and kill" formulation, represented one important control approach. As the seasons progressed chlorpyrifos at 24 fluid ounce per acre (1.68 $\mathrm{kg} / \mathrm{ha}$ ) was used as an overspray.

Deployment of the high-rate PBW Rope during the first two years was limited to sensitive areas near schools, etc. Its use expanded over time reaching a peak in 2003 and then gradually declining to zero over time. The initiation in 2002 of eradication programme activities in part of New Mexico and the Juárez sector of Chihuahua state in Mexico was a major improvement. 
Table 4. Summary data pink bollworm programme in Texas 2000 through 2004

\begin{tabular}{|c|c|c|c|c|c|}
\hline Year & 2000 & 2001 & 2002 & 2003 & 2004 \\
\hline Total acres cotton & 48281 & 48222 & 39538 & 36100 & 40826 \\
\hline$\% B t$-cotton & & 49 & 44 & 35 & 38 \\
\hline $\begin{array}{l}\text { PBW Rope } \\
\text { (acres) }\end{array}$ & & 5399 & 9056 & 23551 & 19815 \\
\hline $\begin{array}{l}\text { Cumulative acres } \\
\text { aerial low-rate } \\
\text { pheromone }\end{array}$ & & 142842 & 123129 & 58017 & 26224 \\
\hline $\begin{array}{l}\text { Acres pheromone }+ \\
\text { insecticide }^{*}\end{array}$ & & 47897 & 43386 & 34945 & 25162 \\
\hline Pyrethroid (acres) & & 0 & 0 & 0 & 2039 \\
\hline Larvae/100 bolls & & 4.53 & 0.81 & 0.13 & 0.76 \\
\hline $\begin{array}{l}\text { Native moths trapped } \\
\text { (million) }\end{array}$ & 1.40 & 0.75 & 0.27 & 0.18 & 0.09 \\
\hline
\end{tabular}

${ }^{*}$ Chlorpyriphos at full labelled rate applied at the same time as a low-rate pheromone Acres treated are also included in low-rate pheromone treated acres

The PBW populations on Pima cotton in the El Paso zone were critical in this state's programme. They accounted for most of the non- $B t$ cotton in the Texas programme. In 2001 Pima made up 51\% of the cotton in the El Paso valley. As a result of the suppression, total trap counts of native moths were reduced from 1.4 million in 2000 (pre-control) to 0.74 million in 2001.

By the end of the last year (2004) without state-wide sterile moth releases, the season-long capture of all moths totalled 0.09 million moths. These moths were captured in traps serviced weekly at one trap per 5-10 acres of cotton. This was the highest trap density used in the programme. The annual pre-control number of native moths per trap per service averaged 17.77 in 2000 vs. less than one in 2004 (0.94).

Larval populations in bolls further illustrate progress during this 4-year suppression period. Each year 60 randomly selected fields were sampled season-long. Larval counts decreased in a steady progressive fashion; details are found in Allen (2005). From an economic perspective it is important to note the general decrease in inputs needed for control including intensively managed aerial application of low-rate pheromones and conventional insecticide.

Limited sterile moth releases on isolated fields was initiated in the Trans-Pecos area in 2004. In 2005, funding for a targeted 10 million sterile moths for release per day was obtained for the core programme area of Texas, New Mexico, and northern Chihuahua. Sterile moths were released season-long in 2005 in Texas and New Mexico. 
In Juárez, Mexico, the start of sterile releases was administratively delayed for some time. During this delay moths earmarked for Mexico were heavily released in Texas along the river border between the two countries. Sterile moth movement into Mexico and therefore coverage, was far better than expected. Eventually moth distribution in 2005 of the targeted 70 million per week were carried out over the entire three state area. At this time non- $B t$ fields were directly targeted by release aircraft. The ability to release these moths in the cotton fields on already suppressed populations before any mated female moth could deposit eggs on a susceptible plant was a game changer. As populations of native PBW declined, sterile moth release numbers were diverted to expanding treatment areas.

Table 5 provides the data for the period 2005-2012, when general sterile moth releases began, until after the last native or unmarked moth was trapped. In 2005, a total of 1336 million sterile moths were released in Texas. Over 1.4 million sterile moths were trapped together with 11917 native moths. With the exception of the year 2009 , this downward trend in native moth capture was very positive as shown in Table 5.

Table 5. Summary data pink bollworm eradication programme Texas programme 2005-2012

\begin{tabular}{|l|r|r|r|r|r|r|r|}
\hline \multicolumn{1}{|c|}{ Year } & 2005 & 2006 & 2007 & 2008 & 2009 & 2010 & 2011 \\
\hline $\begin{array}{l}\text { Total acres } \\
\text { cotton }\end{array}$ & 43358 & 42304 & 39533 & 33029 & 34299 & 38268 & 48447 \\
\hline$\%$ Bt-cotton & 35 & 22 & 30 & 48 & 40 & 49 & 55 \\
\hline $\begin{array}{l}\text { PBW Rope } \\
\text { (acres) }\end{array}$ & 9226 & 9686 & 2843 & 3198 & 1682 & 8050 & 0 \\
\hline $\begin{array}{l}\text { Acres aerial } \\
\text { low-rate } \\
\text { pheromones }\end{array}$ & 6228 & 7597 & 4964 & 0 & 0 & 0 & 0 \\
\hline $\begin{array}{l}\text { Chlorpyrifos } \\
\text { (acres) }\end{array}$ & 2923 & 3653 & 2804 & 0 & 0 & 0 & 0 \\
\hline $\begin{array}{l}\text { Pyrethroid } \\
\text { (acres) }\end{array}$ & 0 & 0 & 3613 & 0 & 0 & 0 & 0 \\
\hline $\begin{array}{l}\text { Sterile moths } \\
\text { recovered } \\
\text { (million) }\end{array}$ & 1.45 & 0.86 & 3.19 & 2.23 & 2.93 & 1.05 & 2.09 \\
\hline $\begin{array}{l}\text { Native moths } \\
\text { trapped }\end{array}$ & 11917 & 3302 & 1363 & 14 & 3291 & 16 & 60 \\
\hline
\end{tabular}

No native moths were trapped in or after 2012. The last pre-season randomly selected monitoring fields with larvae were found in 2005 and 2006. Season-long larvae/100 boll recovery levels in these fields were 0.01 and 0.20 respectively. 
Thereafter no further larvae were found even when fields with positive traps were specifically targeted. The last year conventional insecticides and dual insecticidepheromone treatments were applied was in 2007. This was the result of one hotspot population along the Texas-Mexican border. The two fields with the greatest difficulty were an upland non- $B t$ cotton field on the Mexican side of the border and a 7.9-acre Pima cotton field in Texas, separated by less than $150 \mathrm{~m}$ distance. Larvae had been found late in the season in the Mexican field in 2006. After extensive treatment in 2007 it was not possible to detect larvae. All of these fields were treated with PBW Rope in 2008. In both 2008 and 2009 the only non-sterile inputs were PBW Rope applications.

In 2009, two unexpected events occurred shortly before cotton was harvested. These events were widely separated geographically and with different, but logically, highly probable origins.

The first occurred in and around the Pecos River Valley, where field traps started capturing large numbers of native moths on September 29. Captures were distributed over 6023 acres, with only 30 acres of non-Bt cotton. No native moths had been captured before this time in this area. Historically, wind-borne movement of PBW was common at this time of the year and has been documented frequently in monitoring traps in non-production areas along desert highway trap lines. A storm front movement from an isolated heavily infested organic farm near Midland, Texas, matched this hypothesis. Pierce et al. (2013) strongly verified this conclusion in a 3year study.

The second unexpected event started in the El Paso Valley, October 19, in an area with intensive Pima cotton. On August 22, two irradiation canisters with \pm 180000 moths per container left the Phoenix facility without having proper radiation tags filed. They would have been transported in shipping boxes holding 2.1-2.2 million insects each. All moths captured were in an area documented with GPS flight recorders from this shipment. No native moth captured was more than half a mile ( 0.8 $\mathrm{km}$ ) from a release swath from this flight. The vast majority of the 2626 non-marked moths in the El Paso area were directly within the expected swath of this aircraft. No larvae could be found, although exit holes and some characteristic damage was observed. The capture curves fitted with expected late-season life cycle length. The programme had examined a total of 67246 blooms and bolls prior to the outbreak without any detection. Native moth capture had not occurred in the entire area before October 12. It was only logical to conclude that the unanticipated captures were due to a release of non-irradiated moths. To mitigate this situation, procedures for irradiation safeguarding were reviewed and significantly stiffened at the Phoenix PBW mass-rearing facility.

In 2010, this entire area (8050 acres) was treated with PBW Rope (Table 5) and received enhanced sterile moth releases. The native moths captured in 2010 were scattered throughout the El Paso zone, but not in the PBW Rope treated area. The last native moths captured were in 2011. The Texas PBW programme, as described, has not had a further detected moth or larvae. 


\subsection{Chihuahua, Mexico (Phase I)}

Ing. Alfonso Soto Martinez, Gerente del Comité Estatal de Sanidad Vegetal, 20012008

Ing. Antonio Medina Arroyo, Gerente del Comité Estatal de Sanidad Vegetal, 2009

Ing. Juan Carlos Ramirez Sagahon, Gerente del Comité Estatal de Sanidad Vegetal, 2010-2011

Ing. Antonio Medina Arroyo, Gerente del Comité Estatal de Sanidad Vegetal 20112013

Ing. Jesús Escárcega Terán, Gerente del Comité Estatal de Sanidad Vegetal, 2013 to declaration.

Chihuahua has the largest cotton growing area of any state in Mexico. It is also a state in which production areas grew rapidly during this programme. Eradication of PBW and boll weevil were and are within the same management programme under the Comité Estatal de Sanidad Vegetal. Maps and details for 2002 through 2007 can be found in Staten and Ramirez-Sagahon (2008).

The state programme was ultimately organized in four work units, Ascensión, Meoqui, Ojinaga and Juárez, all in northern Chihuahua (Fig. 1). Trap placement in Chihuahua was standardized at $1 \mathrm{trap} / 4$ ha and 1 trap/20 ha in non- $B t$ and $B t$-cotton respectively.

\subsubsection{Ascensión, Chihuahua}

This work unit included all cotton grown in the north-western portion of the state. This cotton, with only a few exceptions, was grown with a shorter season and colder winter. This is typical of all cotton found in the highland Chihuahua deserts, where centre pivot irrigation predominates. Historically boll damage was sporadic and usually occurred late in the season. With this in mind, the programme was designed to be heavily dependent on the planting of Bt-cotton and PBW Rope treatment. By 2004, the PBW population had been reduced to a level in which sterile insects would not be required.

During the critical initial three years of the programme (2002-2004), the percentage of $B t$-cotton was at $67-69 \%$ (Table 6). During this time all non- $B t$ cotton was treated with PBW Rope. This cotton was well dispersed throughout the cotton production area. Native moth captures decreased by 3.6 and 3.7-fold each year. As the programme progressed, the application rate of PBW Rope was reduced in areas with moderate risk (based on previous year's moth trap capture) from 500 to 250 per ha.

In 2005 some fields did not receive pheromone treatment. Numbers of non- $B t$ fields treated also generally declined with the exception of the 2006 year. This was preceded by the only season to season escalation in native moth captures in traps. This occurred principally late in 2005, when minimum numbers of larvae were found in non-Bt monitoring field searches (less than 10). 
By 2006 only 38\% of the cotton was Bt-cotton (Table 6). 2006 had the only appreciable escalation of PBW Rope use. Conventional insecticides were used in only two years directly for PBW suppression. The last native moth capture in the Ascensión area of Chihuahua was in 2007 (12 specimen). Staten and Ramirez-Sagahon (2008) noted that this represented two native moths per every 10000 traps serviced.

Table 6. Summary data pink bollworm eradication programme for the Ascension area of the state of Chihuahua

\begin{tabular}{|l|r|r|r|r|r|r|r|r|}
\hline \multicolumn{1}{|c|}{ Year } & \multicolumn{1}{|c|}{2002} & \multicolumn{1}{c|}{2003} & 2004 & 2005 & 2006 & 2007 & 2008 & 2009 \\
\hline $\begin{array}{l}\text { Total hectares } \\
\text { (ha) }\end{array}$ & 11268 & 16499 & 25637 & 23088 & 28430 & 29228 & 26632 & 10209 \\
\hline \% Bt-cotton & 69 & 68 & 67 & 47 & 38 & 29 & 30 & 31 \\
\hline $\begin{array}{l}\text { PBW Rope } \\
\text { (ha) }\end{array}$ & 3507 & 5177 & 8566 & 8936 & 13110 & 1118 & 461 & 0 \\
\hline $\begin{array}{l}\text { Insecticides } \\
\text { (ha) }\end{array}$ & 581 & 0 & 0 & 86.9 & 0 & 0 & 0 & 0 \\
\hline \begin{tabular}{l} 
Native moths \\
\hline
\end{tabular} & 20256 & 5489 & 1467 & 4204 & 63 & 12 & 0 \\
\hline
\end{tabular}

${ }^{*}$ Conventional aerially applied insecticides expected locally to be the most effective

\subsubsection{Meoqui, Chihuahua}

This unit is Chihuahua's southern-most cotton growing area. This area of Chihuahua is bordered by the states of Coahuila and Durango. It contained all the cotton cultivation found around the cities of Delicias and Jimenez. It is an older, diverse production unit mostly using impounded water from the Rio Conchos. It has enough overwintering habitat to make boll weevil its key pest.

Area-wide treatment for both PBW and boll weevil started in 2002. The weevil required ULV malathion with emphasis on pin square treatments and treatments in mid- and late-season based on weevil trap captures. This was followed by treatments targeting weevils going into diapause. A high percentage of Bt-cotton was present in all years except 2006 (Table 7). The PBW Rope was ideally suited for use in these circumstances. In the initial three years (2002-2004), all non-Bt cotton was treated with PBW Rope; application was targeted for 6 leaf cotton in the spring.

In 2005, PBW Rope was applied in the spring on non- $B t$ fields that had positive trap captures the previous year or at detection in early and mid-season. Only in the first year were 44.3 ha treated for PBW with a conventional insecticide and a sprayable pheromone, in addition to PBW Rope. Suppression in these fields was triggered where even a single larva was found by targeted scouting. No aerial treatments were applied thereafter. 
Table 7. Summary data pink bollworm eradication programme for the Meoqui area of Chihuahua

\begin{tabular}{|c|c|c|c|c|c|c|c|c|c|}
\hline Year & 2002 & 2003 & 2004 & 2005 & 2006 & 2007 & 2008 & 2009 & 2010 \\
\hline $\begin{array}{l}\text { Total hectares } \\
\text { (ha) }\end{array}$ & 930 & 5151 & 9332 & 6754 & 4332 & 933 & 1588 & 45 & 1704 \\
\hline Non-Bt (ha) & 164 & 380 & 278 & 321 & 2195 & 114 & 266 & 2 & 254 \\
\hline$\% B t$-cotton & 82 & 93 & 97 & 95 & 49 & 88 & 83 & 99 & 85 \\
\hline $\begin{array}{l}\text { PBW Rope } \\
\text { (ha) }\end{array}$ & 164 & 380 & 278 & 180 & 139 & 25 & 12 & 0 & 0 \\
\hline $\begin{array}{l}\text { Insecticides } \\
\text { (ha) }\end{array}$ & 44.3 & 0 & 0 & 0 & 0 & 0 & 0 & 0 & 0 \\
\hline $\begin{array}{l}\text { Native moths } \\
\text { trapped }\end{array}$ & N/A* & 377 & 2970 & 1203 & 13410 & 2632 & 953 & 265 & 0 \\
\hline
\end{tabular}

${ }^{*} N / A=$ not available; 5046 moths were captured in the combined Meoqui and Ojinaga work units

Unfortunately, native moth capture summary data for 2002 are not available as they were combined for the areas of the Ojinaga and Meoqui work units. Throughout the programme in Chihuahua, trap grids were not completely established until July 2002. During this programme's 2002 establishment period, boll weevil treatment and trapping, as well as PBW Rope application, required availability of early-season resources.

Weekly PBW trap data as reported in Staten and Ramirez-Sagahon (2008) provide an understanding of important occurrences in the first two years, with graphics showing separate weekly trap captures for each area. There were appreciable trap captures in 2002. In 2003, captures were reduced season-long, however, in Meoqui during September 2004, trap capture of native PBW escalated. From September to the last service date in October 2914 moths were captured with no correlation to non- $B t$ fields. Migration was suspected but not verified.

In 2006 no moth captures occurred anywhere in Meoqui before the week of September 11. From that point on, there was a massive escalation in captures throughout the region with no correlation to non-Bt cotton. This included a new growing area with no PBW history and major captures in new $B t$-fields with no cotton history. Highway trap lines were quickly established to the cotton growing area south of the state of Chihuahua in the La Laguna area, in the states of Coahuila and Durango, and to the Texas-Mexico border in Ojinaga. The conclusion, that a major weatherdriven migration was responsible, was inescapable.

In 2007, many of the PBW positive fields were shifted to Bt-cotton or other crops. PBW Rope use continued but declined. By 2009 no treatment for PBW was needed. There have been no further PBW captures since 2009. By 2010, the La Laguna area was moving forward for a combined PBW and boll weevil programme. 


\subsubsection{Ojinaga, Chihuahua}

This work unit, as stated above, was managed together with the Meoqui unit for three years. It had two distinct habitats for boll weevil and PBW. A well-established area was in a surface irrigated system at the confluence of the Rio Concho and the Rio Bravo (Grande, USA) rivers. This area is a local commerce centre at Presidio, Texas and Ojinaga, Chihuahua. Initially Texas had some cotton on its side of the border. On the Mexican side, removed from this river valley, where rapidly developing areas of centre pivot irrigation. The growing season in these areas is shorter than in the cotton areas in the river valley. Its rapid expansion is reflected in the increase in cotton areas (Table 8).

During the initial three years all the non-Bt cotton was treated with PBW Rope. Need and use of pheromone was reduced thereafter; the last treatment for PBW occurred in 2010 on 78 ha. No conventional insecticides were used for PBW in the Ojinaga unit. Boll weevil was treated with ULV malathion.

Table 8. Summary data pink bollworm eradication programme for the Ojinaga area of Chihuahua

\begin{tabular}{|c|c|c|c|c|c|c|c|c|c|}
\hline Year & 2002 & 2003 & 2004 & 2005 & 2006 & 2007 & 2008 & 2009 & 2010 \\
\hline $\begin{array}{l}\text { Total hectares } \\
\text { (ha) }\end{array}$ & 1382 & 3987 & 9541 & 10936 & 20102 & 19885 & 19611 & 12585 & 27220 \\
\hline$\% B t$-cotton & 42 & 52 & 82 & 85 & 81 & 60 & 42 & 69 & 86 \\
\hline Pheromone (ha) & 803 & 1907 & 1715 & 130 & 245 & 769 & 248 & 315 & 78 \\
\hline Insecticides (ha) & 0 & 0 & 0 & 0 & 0 & 0 & 0 & 0 & 0 \\
\hline $\begin{array}{l}\text { Native moths } \\
\text { trapped }\end{array}$ & N/A* & 390 & 79 & 4 & 5415 & 96 & 225 & 89 & 0 \\
\hline
\end{tabular}

${ }^{*} N / A=$ not available, 5046 native moths were captured in the combined Meoqui and Ojinaga work units

As noted in Staten and Ramirez-Sagahon (2008), native moth captures were common when traps were deployed in 2002. With area-wide suppression, numbers dropped drastically in the following years through 2005, when only four PBW moths were captured. However, as detailed in the discussion of the Meoqui unit, Ojinaga's 2006 trap captures exploded. A continued declining south to north gradient was apparent, with the largest portion of total captures occurring in the southern part of this area near Camargo, Chihuahua. The lowest captures occurred in the river valley on the Texas-Chihuahua border. 
A season total of 5415 PBW moths were recovered in 2006. This escalation started during the reporting week of September 24, as was true of the Meoqui area. Native PBW had not been detected before this time in 2006. Similar patterns of capture occurred through 2009. Nevertheless, the last moth detections were in 2009 at 89 moths for that season. In 2010 no moths were detected with trap services exceeding 4000 traps per week.

\subsubsection{Juárez, Chihuahua}

This unit contained the state of Chihuahua's most destructive PBW populations. Its situation was inseparable from the El Paso, Texas valley unit as described in the Texas Section. The major differences were in a latter programme starting date (2002) and the absence of Pima cotton. Cotton was largely non- $B t$ in the Juárez unit and non- $B t$ cotton fields on the Mexican side of the border were all $G$. hirsutum varieties (upland cotton).

The first year's start was with a short time frame as described in the previous areas of Chihuahua. This unit started with only the cotton areas in the Rio Bravo (Rio Grande, USA) River Valley. As time progressed, new centre pivot irrigated cotton areas near Villa Ahumada, south of Juárez, were added to the unit. This centre pivot cotton did not create problems. Bt-cotton was primarily grown in the outskirts of the city of Juárez's urban interfaces. This scattered cotton production was found in the north-western end of the valley. Bt-cotton ranged from 33\% in 2002 to $13 \%$ in 2008 (Table 9).

Table 9. Summary data pink bollworm eradication programme for the Juárez area of Chihuahua

\begin{tabular}{|c|c|c|c|c|c|c|c|c|}
\hline Year & 2002 & 2003 & 2004 & 2005 & 2006 & 2007 & 2008 & 2009 \\
\hline $\begin{array}{l}\text { Total hectares } \\
\text { (ha) }\end{array}$ & 5251 & 7579 & 8689 & 7915 & 8898 & 7625 & 7371 & 5052 \\
\hline$\% B t$-cotton & 33 & 24 & 29 & 29 & 23 & 20 & 13 & 18 \\
\hline $\begin{array}{l}\text { PBW Rope } \\
\text { (ha) }\end{array}$ & 3528 & 5736 & 6177 & 1070 & 1063 & 1159 & 194 & 155 \\
\hline $\begin{array}{l}\text { Insecticides } \\
\text { (ha) }\end{array}$ & 697 & 60 & 70 & 30 & 0 & 114 & 0 & 0 \\
\hline $\begin{array}{l}\text { Sterile moths } \\
\text { released } \\
\text { (millions) }\end{array}$ & 0 & 0 & 0 & 69.4 & 205.7 & 346.5 & 371.9 & 344.5 \\
\hline $\begin{array}{l}\text { Native moths } \\
\text { trapped }\end{array}$ & 9886 & 5573 & 1247 & 1108 & 1957 & 447 & 4 & 0 \\
\hline
\end{tabular}


Conventional insecticide was most heavily applied at the start of the year 2002; in total 697 aggregate ha were treated over that season. The second highest aggregate treatment occurred in 2007 at 114 ha. Use of aerially applied insecticides was limited to $30-70$ ha in 2003-2005. All non- $B t$ fields were treated with PBW Rope during the initial three years of operations (2002-2004). As in other areas of Chihuahua, detection thresholds were used after 2004 and PBW Rope treatments declined after that year.

In 2002 native moth captures were the most intense of any area in Chihuahua. From August 25 to November 10, a total of 9486 native moths were captured in 11586 total traps serviced. As in other areas of Chihuahua, native moth captures declined during subsequent years (Staten and Ramirez-Sagahon 2008).

By 2006 and 2007, the majority of all captures were recovered in one general area of the state of Chihuahua, which was contiguous with fields on the Texas side of the border. In 2008, the Chihuahua programme successfully encouraged producers to shift most of these fields to Bt-cotton. The last native PBW in the Juárez unit were trapped in 2008 .

In 2010 and 2012, PBW Rope was applied to 129 and 153 ha respectively, in coordination with Texas treatments targeting finds in adjacent Texas fields still with native moth captures. These treatments were triggered based on late-season captures in 2009 and 2011 in Texas (Table 5). Sterile moth releases, started in 2005, therefore continued through 2012 at 180.2, 119.8, and 118.3 million per year. This was done in concert with Texas captures in adjacent fields. There is no ecological separation between the two areas.

\subsection{New Mexico, USA (Phases I and II)}

Joe Friesen, Executive Director PBW and BW Foundation, 1999-2013

Patrick Sullivan, Executive Director PBW and BW Foundation, 2013 to present

The New Mexico Phase I programme, managed by the New Mexico PBW and BW Foundation, covered all the cotton along the Rio Grande River in the Mesilla Valley and the Hatch Valley (Fig. 1). These two valleys follow the river from El Paso, Texas, north to the Caballo Lake Dam ( \pm 100 miles), where cotton is no longer a dominant crop. This area, established before 1930, has a diversified agriculture with a high percentage of its area dedicated to pecans, peppers, vegetables, alfalfa, and grain. Urban interface is significant around its biggest city of Las Cruces. The majority of cotton acreage is in these two valleys, where it is irrigated with lake-stored water supplemented with groundwater in close proximity to the river.

A smaller area of cotton production is found further west near Deming, New Mexico. It is pump-irrigated and similar to the Ascensión area of Chihuahua, Mexico south of this part of New Mexico. Details for the PBW programme for the years 2000 through 2007 can be found in Friesen and Staten (2008). In four of the first five years of the programme, non- $B t$ exceeded $B t$-cotton (Table 10). Non- $B t$ cotton was made up of Pima and upland cotton in order of importance. Of this cotton, 2-5\% was certified organic. 
From 2002 through 2004 all non-Bt cotton was treated with PBW Rope. As outlined in Friesen and Staten (2008) this was complicated by local cultivation practices applied for weed control. Cotton was planted in nearly flat low beds, but then cultivation raised the soil in the plant row while forming a deep furrow. As a result, PBW Rope applied at the 6th leaf node on a young plant was quickly covered in dirt. Pheromone emission was therefore blocked rendering the treatment ineffective.

To overcome this cultivation problem, in 2003 sprayable pheromones and dual insecticide-pheromone treatments were applied from ground spray rigs and by air at a targeted 10-day interval until the PBW Rope could be applied. This was logistically difficult and drastically increased programme input costs. It also contributed to the higher than expected usage of sprayable pheromones and insecticide shown in Table 10.

Table 10. Summary data pink bollworm eradication programme in New Mexico (Phase I)

\begin{tabular}{|c|c|c|c|c|c|c|c|c|}
\hline Year & 2002 & 2003 & 2004 & 2005 & 2006 & 2007 & 2008 & 2010 \\
\hline Total acres & 17061 & 21061 & 21701 & 21722 & 21627 & 16957 & 14664 & 13246 \\
\hline$\% B t$-cotton & 37 & 51 & 46 & 45 & 36 & 80 & 74 & 76 \\
\hline PBW Rope (acres) & 10690 & 9300 & 9493 & 1991 & 627 & 1325 & 0 & 0 \\
\hline $\begin{array}{l}\text { Acres aerial } \\
\text { pheromone }\end{array}$ & 0 & 17025 & 9843 & 3445 & 0 & 63 & 0 & 0 \\
\hline $\begin{array}{l}\text { Acres pheromone } \\
+ \text { insecticide }\end{array}$ & 0 & 13115 & 4806 & 255 & 0 & 0 & 0 & 0 \\
\hline $\begin{array}{l}\text { Mean traps } \\
\text { serviced/week }\end{array}$ & 1782 & 1906 & 2371 & 2231 & 1652 & 910 & 412 & 633 \\
\hline $\begin{array}{l}\text { Sterile moths } \\
\text { (millions) }\end{array}$ & & & & N/A & 322.7 & 365.9 & 307 & \\
\hline $\begin{array}{l}\text { Sterile moths } \\
\text { recovered }\end{array}$ & & & & & 330308 & 394842 & 279385 & 15907 \\
\hline Larvae detected & & 227 & 2 & 0 & 0 & 0 & 0 & 0 \\
\hline $\begin{array}{l}\text { Native moths } \\
\text { trapped }\end{array}$ & 51764 & 126033 & 18126 & 2978 & 203 & 15 & 0 & 1 \\
\hline
\end{tabular}


Treatments were concentrated in pockets. By 2005 this level of treatment could be reduced. Even so, with over 11900 acres of non-Bt cotton, only a combined cumulative 3703 acres of sprayable pheromone and conventional insecticides were applied. PBW Rope applications in 2007 were based largely on native moth captures in 2006. The last year of pheromone treatment in the New Mexico programme was 2007.

Sterile moth releases started on a partial, "experimental" basis in Deming, Hatch, and north of Las Cruces in 2004. The entire area received its first full complement of sterile moths in 2005. Although $B t$-fields were not specifically targeted, sterile moths were present in all fields. In 2007, all non- $B t$ fields received direct sterile moth releases. Less than $50 \%$ of these non- $B t$ fields required any additional pheromone treatment.

Native moth captures were again used to document the decline of detectable populations. In 2003, total counts were much higher than in the first year (2002). Nevertheless, in 2001 pre-programme captures of moths per trap per week still peaked at \pm 7 times greater when compared to similar data for 2003. Post-2003 captures of native moths declined each year through 2007, when only 15 native moths were trapped for the entire year.

In 2010 one moth was captured in a field just north of El Paso, Texas, which abutted a Texas field with concurrent late-season captures. These fields were literally separated by a line on a map representing no more than 20 feet in distance. This small area was included in the Texas sterile moth release operations for the remainder of the 2010 season and in 2011.

By 2006, cotton in Chavis, Eddy, and Lee counties of New Mexico was managed by contract as part of the Texas boll weevil eradication programme. During this time the area was under extensive ULV malathion treatment for boll weevil. The cotton produced was predominantly Bt-cotton. Pierce et. al. (2013) discusses the last 9 moth captures in 2009. All evidence indicates these captures were remnants of the same population movement that affected the Pecos valley area of Texas in that same time frame. In that study no New Mexico captures occurred in 2010 and 2011. APHIS records show negative surveys in 2011 to 2015.

In Hidalgo county, a small area of cotton production on the Gila river at the Arizona-New Mexico border was managed in Phase II as part of Arizona's Safford district (Section 4.4.1.) without separation of data.

\subsection{Arizona, USA (Phases II, IIIa and IIIb)}

Larry Antilla, ACRPC Director, 1991-2011

Leighton R. Liesner, ACRPC Director, 2011 to present

The Arizona Cotton Research and Protection Council (ACRPC) was established in 1984 to deal with an outbreak of boll weevil in Arizona. The outbreak was rapidly expanding in scope. The resulting programme culminated in declared boll weevil eradication in 1991 (Neal and Antilla 2001). The organization remained intact for continued monitoring of boll weevil and PBW populations. Its numerous projects included the successful Parker area-wide mating disruption trial, as noted previously. 
It became a model for other areas of what could be accomplished. It was the key example used to convince Texas growers to make a first commitment to eradication (Allen et al. 2005).

The organization became deeply involved in a coordinated programme to address area-wide resistance management of PBW in Bt-cotton with the University of Arizona (Tabashnik et al. 2000; Antilla et al. 2001; Dennehy et al. 2004). The understanding of the presence of resistance and its risk potential was intense. As an issue and threat, it was completely controlled as exemplified by declines of resistance expression (Tabashnik et al. 2010, 2013).

When sterile moths became available, the organization was in place for an areawide eradication programme. It had extensive pre-programme population monitoring data and knowledge of the relevant areas. The ACRPC and the University of Arizona were critical in clearing and implementing a special state $24 \mathrm{C}$ label allowing the utilization of sterile insects in lieu of structured non- $B t$ cotton refugia for PBW resistance management. A 2005 revised EPA primary Bt-cotton label issued for 2006 could have ended eradication efforts as they would have rendered some cotton untreatable (see transgenic cotton Section 3.3.1. of this chapter).

\subsubsection{Eastern Three Fourths of Southern Arizona (Phase II)}

With the passage of a grower-approved referendum on PBW eradication funding in 2005, Arizona's ACRPC started its first year with all tools at their disposal in 2006. It started in approximately $85 \%$ of cotton state-wide. It constituted all cotton in surface and groundwater irrigated areas within the eastern three fourths of southern Arizona (Fig. 1, Phase II).

As shown in Table 11, of the 165683 acres, 93.1\% were Bt-cotton in 2006. The Safford Valley exceeded this overall average, providing the majority of the Phase II area's non-Bt cotton. During this time, much of the cotton planted was Pima ( $G$. barbadense).

An unpublished cooperative effort with ACRPC, USDA-CPHST, and Pacific BioControl led the development of the application technology of PBW Rope prewound on a bamboo stick in lieu of the ropes being directly "tied" on small cotton plants. This allowed ACRPC to mechanize treatments for many of their non- $B t$ fields. In all non- $B t$ fields, treatment could thus be initiated earlier. Arizona was successful in applying PBW Rope on all non-Bt cotton in 2006-2009. Late 2011 native moth captures led Arizona to again treat all non-Bt cotton with PBW Rope in 2012. As shown in Table 11, aerially applied pheromone treatments declined from 2006 to 2010 (from 6409 to 0 ).

In 2006, Arizona treated a cumulative 6409 acres with conventional insecticides predominantly on a small cluster of fields near Eloy. This event did not reoccur in subsequent years. All conventional insecticide use was eliminated in 2009. Arizona conducted boll surveys in late-season as part of an ongoing $B t$ resistance monitoring programme. Larval PBW populations ceased to be detectable by 2009 in this portion of the state. Adult PBW capture decline from 2006, the first year of treatment, through 2011, was equally impressive. 
Table 11. Summary data pink bollworm eradication programme in Arizona (Phase II - Arizona Zone 1)

\begin{tabular}{|c|c|c|c|c|c|c|c|c|}
\hline Year & 2006 & 2007 & 2008 & 2009 & 2010 & 2011 & 2012 & 2013 \\
\hline Total acres & 165683 & 145947 & 118435 & 124191 & 168255 & 213413 & 159244 & 136244 \\
\hline $\begin{array}{l}\text { Non- } B t \\
\text { acres } \\
(\%)\end{array}$ & $\begin{array}{r}11465 \\
(6.9)\end{array}$ & $\begin{array}{l}6389 \\
(4.4)\end{array}$ & $\begin{array}{l}2029 \\
(1.7)\end{array}$ & $\begin{array}{l}2144 \\
(1.7)\end{array}$ & $\begin{array}{l}7387 \\
(4.4)\end{array}$ & $\begin{array}{r}11946 \\
(5.6)\end{array}$ & $\begin{array}{l}6607 \\
(4.1)\end{array}$ & $\begin{array}{l}4427 \\
(3.2)\end{array}$ \\
\hline $\begin{array}{l}\text { PBW Rope } \\
\text { (acres) }\end{array}$ & 11465 & 6389 & 2029 & 2144 & 0 & 0 & 6607 & 0 \\
\hline $\begin{array}{l}\text { Acres aerial } \\
\text { pheromone }\end{array}$ & 6409 & 1458 & 31 & 64 & 0 & 0 & 0 & 0 \\
\hline $\begin{array}{l}\text { Insecticides } \\
\text { (acres) }\end{array}$ & 2907 & 1197 & 62 & 0 & 0 & 0 & 0 & 0 \\
\hline $\begin{array}{l}\text { Sterile moth } \\
\text { releases } \\
\text { (millions) }^{*}\end{array}$ & 1682 & 1443 & 1410 & 1990 & 1123 & 1593 & 1300 & 382 \\
\hline $\begin{array}{l}\text { Sterile } \\
\text { moths } \\
\text { recovered } \\
\text { (millions) }\end{array}$ & 1.447 & 0.918 & 0.551 & 0.307 & 1.137 & 1.047 & 0.489 & 0.012 \\
\hline $\begin{array}{l}\text { Larvae } \\
\text { detected } \\
(\%)\end{array}$ & $\begin{array}{l}1126 \\
(2.0)\end{array}$ & $\begin{array}{r}31 \\
(0.08)\end{array}$ & $\begin{array}{r}2 \\
(0.02)\end{array}$ & 0 & 0 & 0 & 0 & \\
\hline $\begin{array}{l}\text { Native } \\
\text { moths } \\
\text { trapped }\end{array}$ & 657752 & 199726 & 2306 & 866 & 453 & 566 & 0 & 0 \\
\hline
\end{tabular}

*In 2006, California Phase IIIa's release numbers are included in this table

\subsubsection{North of Yuma Arizona along the Colorado River (Phase IIIa)}

Eradication treatments of cotton areas north of the Yuma, Arizona area along the Colorado River (Fig. 1) began in 2007. It included the Parker and Mojave valleys along the Colorado River. Southern California started its eradication treatments at the same time. The area had high ratios of $B t$ - to non- $B t$ cotton (Table 12). Prior to 2007 many of the growers in this area used the un-treated non- $B t$ cotton option (5\%) for resistance management. At least some of this was not harvested (sacrificed) due to PBW damage.

With the initiation of sterile moth releases for resistance management, all non- $B t$ cotton could be and was treated at or just before 6 leaf with PBW Rope on a bamboo stake. This occurred from 2007 through 2010, and in 2012. The decision to treat in 2012 was state-wide after unexpected increases in late 2011 (see above). With a preponderance of $B t$-cotton, PBW Rope treatment, and sterile moth releases, the need for sprayable pheromone and conventional insecticides ended quickly (Table 12). 
Throughout the pheromone-treatment years, the majority of all native moth captures were actually in $B t$-cotton, either near a non- $B t$ cotton field or in fields which were rotated out of a non- $B t$ refuge field the previous year. Captures were reduced by 97.9\% between 2007 and 2008. Larval populations were no longer detectable after 2007.

Table 12. Summary data pink bollworm eradication programme in Arizona (Phase IIIa - Arizona Zone 2)

\begin{tabular}{|c|c|c|c|c|c|c|c|c|}
\hline Year & $2006^{*}$ & 2007 & 2008 & 2009 & 2010 & 2011 & 2012 & 2013 \\
\hline Total acres & N/A & 16546 & 12835 & 12108 & 18654 & 28940 & 24204 & 19485 \\
\hline \multirow{2}{*}{$\begin{array}{l}\text { Non- } B t \text { acres } \\
(\%)\end{array}$} & \multirow{2}{*}{ N/A } & 509 & 993 & 1812 & 1116 & 1278 & 299 & 285 \\
\hline & & (3.1) & (7.7) & (15) & (6) & (4.4) & (1.2) & (1.5) \\
\hline $\begin{array}{l}\text { PBW Rope } \\
\text { (acres) }\end{array}$ & N/A & 509 & 993 & 1812 & 1116 & 0 & 299 & 0 \\
\hline $\begin{array}{l}\text { Areal } \\
\text { pheromone } \\
\text { (acres) }\end{array}$ & N/A & 290 & 0 & 111.5 & 0 & 0 & 0 & 0 \\
\hline $\begin{array}{l}\text { Conventional } \\
\text { (acres) }\end{array}$ & N/A & 117 & 0 & 0 & 0 & 0 & 0 & 0 \\
\hline $\begin{array}{l}\text { Sterile moths } \\
\text { recovered }\end{array}$ & N/A & 56689 & 47432 & 32546 & 18125 & 17150 & 21904 & 10 \\
\hline Larvae detected & 784 & 31 & 0 & 0 & 0 & 0 & 0 & 0 \\
\hline $\begin{array}{l}\text { Native moths } \\
\text { trapped }\end{array}$ & N/A & 155104 & 3259 & 1183 & 36 & 17 & 0 & 0 \\
\hline
\end{tabular}

* Pre-programme treatment

\subsubsection{Yuma and Lower Colorado Basin (Phase IIIb)}

The profile of the Yuma area, Phase IIIb was similar to Phase IIIa and the rest of the Lower Colorado Basin (Fig. 1). In all these areas, when non-Bt cotton is produced full season, the PBW population development potential is extensive, as most of the winter is frost-free. Fortunately, in Yuma most of the cotton is rotated with high value winter vegetables. That portion of the area's cotton crop is terminated in August and September. Consequently, the PBW population growth potential from September through November is severely curtailed in these fields. This, and high percentages of $B t$-cotton, was extremely important in potential PBW population reduction (Table 13). 
All non-Bt fields were treated with PBW Rope for the first five years of programme operations. A portion of the non- $B t$ fields were treated with aerially applied pheromone in 2008 and 2009 after PBW Rope efficacy ended. Conventional insecticides were only needed in 2008 and were minimal. Larval populations were not detected after 2009. After 2007, pre-programme survey moth captures declined sharply with no native moth captures in 2011 and one in 2012.The one capture in 2012 was in early April before hostable fruit set. It was the last native moth detection in the programme in the USA.

Table 13. Summary data pink bollworm eradication programme in Arizona (Phase IIIb - Arizona Zone 3)

\begin{tabular}{|c|c|c|c|c|c|c|c|}
\hline Year & $2007^{*}$ & 2008 & 2009 & 2010 & 2011 & 2012 & 2013 \\
\hline Total acres & N/A & 10358 & 12957 & 15571 & 24676 & 19116 & 11502 \\
\hline $\begin{array}{l}\text { Non-Bt acres } \\
(\%)\end{array}$ & N/A & $\begin{array}{r}236 \\
(2.3)\end{array}$ & $\begin{array}{r}717 \\
(5.5)\end{array}$ & $\begin{array}{r}344 \\
(2.2)\end{array}$ & $\begin{array}{l}2010 \\
(8.1)\end{array}$ & $\begin{array}{r}458 \\
(2.4)\end{array}$ & $\begin{array}{r}178 \\
(1.5)\end{array}$ \\
\hline PBW Rope & N/A & 236 & 714 & 344 & 2010 & 458 & 0 \\
\hline $\begin{array}{l}\text { Acres aerial } \\
\text { pheromone }\end{array}$ & N/A & 248 & 930 & 0 & 0 & 0 & 0 \\
\hline $\begin{array}{l}\text { Conventional } \\
\text { (acres) }\end{array}$ & N/A & 386 & 0 & 0 & 0 & 0 & 0 \\
\hline $\begin{array}{l}\text { Sterile moths } \\
\text { recovered }\end{array}$ & N/A & 11861 & 75027 & 39718 & 75822 & 75961 & 130978 \\
\hline $\begin{array}{l}\text { Larvae } \\
\text { detected }\end{array}$ & 44 & 7 & 2 & 0 & 0 & 0 & 0 \\
\hline $\begin{array}{l}\text { Native moths } \\
\text { trapped }\end{array}$ & 61166 & 21032 & 4175 & 85 & 0 & 1 & 0 \\
\hline
\end{tabular}

*Pre-programme operations

\subsection{Southern California, USA (Containment Programme, Phases IIIa and IIIb)}

Jodie Brigman District, Supervisor CDFA, 2001-2017

Jim Rudig, Programme Manager CDFA, 2006-2011

Victoria Hornbaker, Programme Manager CDFA, 2011, interrupted, current

The California organization (California Cotton Pest Control Board, CCPCB) was in place and operating in southern California before 2007, with all needed CDFA staff 
working on PBW activities, including the long-standing San Joaquin Valley containment/exclusion programme. They were deeply involved in population monitoring particularly in long standing monitoring of seasonal PBW movement throughout the area. Important efforts included monitoring for $B t$ resistance management in cooperation with the other states, led by the University of Arizona (Dennehy et al. 2004).

When PBW invaded southern California in 1963-64, the Imperial Valley, the Coachella Valley, and the Blythe-Palo Verde Valley had an extensive and prosperous cotton industry, frequently comprising more than 100000 acres. Before PBW establishment, southern California produced very high yields with limited, targeted insecticide. The tenets of integrated pest management pioneered here, as described by Stern et al. (1959), had become a world standard.

In this southern California area, cotton was produced using a February-March planting window and harvested well into December. As part of the Lower Colorado River Basin (Fig. 1), with its neighbours of Yuma in Arizona, San Luis Río Colorado in Sonora, and Mexicali in Baja California, cotton's long-season growth regimen allowed the introduction and establishment of PBW to produce more generations per season than anywhere else in its North American range. Results of the invasion were significant yield losses and extensive insecticide use. Secondary pests, exemplified by whitefly, became common.

By the time southern California entered the PBW eradication programme in 2007, neither the Coachella Valley, nor the Imperial Valley had any commercial cotton. Only the Blythe area, the Palo Verde Valley, Bard/Winterhaven area (adjacent to Yuma), and Needles north of Parker, still produced some cotton in southern California. Most importantly, southern California had the highest ratio of Bt- to nonBt cotton of any area in the programme (Table 14).

Southern California was unique in that it also had a small but important okra production. Okra is a weak host for PBW in the south-western USA and PBW has a decided preference for cotton. In addition, okra pods are harvested before larvae can develop, serving as a mechanical control. In the above agronomic environment, no conventional insecticides or sprayable pheromone systems were used. All non- $B t$ cotton was treated with PBW Rope from 2007-2011. Okra in the Imperial Valley was treated with PBW Rope for the initial three years. PBW Rope was also applied in the Coachella valley in 2008 .

The small amount of non- $B t$ cotton was targeted at the onset of the programme at the standard mean of 250 sterile moths/acre/day (618/ha/day). All okra was targeted at a mean of 200 sterile moths/acre/day. In their most important role, sterile moth releases were used for PBW resistance prevention and management. Bt-cotton was targeted at a standard of 10 sterile moths/acre/day (24.7/ha/day). Adult moth monitoring showed a consistently decreasing number of native PBW moths captured each year that the programme progressed (Table 14).

The last native moth was captured in southern California in 2011. It was captured in a highway trap line, not in a field trap. 
Table 14. Summary data pink bollworm eradication programme in southern California

\begin{tabular}{|l|r|r|r|r|r|r|r|}
\hline \multicolumn{1}{|c|}{ Year } & \multicolumn{1}{|c|}{2007} & \multicolumn{1}{|c|}{2008} & 2009 & 2010 & 2011 & 2012 & 2013 \\
\hline Total acres cotton & 1655 & 9635 & 6132 & 10445 & 19175 & 18293 & 16171 \\
\hline $\begin{array}{l}\text { Non-Bt acres } \\
\text { (\%) }\end{array}$ & 130 & 30 & 71 & 0 & 85 & 105 & 30 \\
\hline $\begin{array}{l}\text { Okra (acres) } \\
\text { PBW Rope cotton } \\
\text { (acres) }\end{array}$ & 130 & $(0.3)$ & $(1.1)$ & $(0.0)$ & $(0.4)$ & $(0.6)$ & $(0.2)$ \\
\hline $\begin{array}{l}\text { PBW Rope okra } \\
\text { (acres) }\end{array}$ & 205 & 460 & 597 & 560 & 513 & 555 & 515 \\
\hline $\begin{array}{l}\text { Sterile moths } \\
\text { released (millions) }\end{array}$ & 76.46 & 72.15 & 36.71 & 124.74 & 5.27 & 1.25 & 0 \\
\hline $\begin{array}{l}\text { Native moths } \\
\text { trapped }\end{array}$ & 447067 & 16395 & 6142 & 147 & 0 & 0 & 0 \\
\hline
\end{tabular}

\subsection{Northern Sonora, Mexico (Phase IIIa)}

Ing. Javier Valenzuela Lagarda, Gerente de Comité de Sanidad Vegetal, 2006 to declaration.

The cotton growing area of northern Sonora is found predominantly along the lower Colorado River in San Luis Río Colorado. In addition, it includes cotton in Sonoyta on the Arizona/Sonora border more than $200 \mathrm{~km}$ to the east. The Sonoyta data include scattered fields near the city of Caborca. In the latter, like much of Sonora's southern coastal production areas, agriculture has shifted to vegetable production. At this time no cotton production remains in Caborca. The only other cotton in Sonora during this programme was in the state's southern coastal areas. The Sonoyta area was limited and of a shorter season than San Luis. The San Luis growing area is separated from the Yuma, Arizona growing area by the small twin cities of San Luis Río Colorado and contiguous San Luis, Arizona. It is separated from the Mexicali Valley of Baja California only by the normally dry Colorado River and riparian area. The cotton is planted in early March through mid-April. In San Luis irrigation for cotton production is limited after August. This limits reproduction in later generations of PBW.

During 2007 and 2008, only non-Bt-cotton was produced in the Sonoyta / Caborca area. By 2013, this trend was completely reversed in favour of Bt-cotton in Sonoyta, while after 2010 the scattered fields around Caborca were no longer in cotton. The increased ratio of $B t$ - to non- $B t$ cotton was more pronounced in San Luis proper as well. By $2013,99 \%$ of all cotton was $B t$ as illustrated in summary Table 15 . 
Table 15. Northern Sonora, Mexico pink bollworm eradication programme summary data

(Phase IIIb, Figure 1)

\begin{tabular}{|c|c|c|c|c|c|c|c|}
\hline Year & 2007 & 2008 & 2009 & 2010 & 2011 & 2012 & 2013 \\
\hline $\begin{array}{l}\text { Total hectares } \\
\text { (ha) }\end{array}$ & 3126 & 3885 & 2974 & 3657 & 6881 & 6751 & 3515 \\
\hline$\% B t$-cotton & 54 & 72 & 75 & 87 & 91 & 92 & 99 \\
\hline $\begin{array}{l}\text { Pheromones } \\
\text { (ha) }\end{array}$ & 1425 & 1093 & 751 & 478 & 550 & 237 & 10 \\
\hline $\begin{array}{l}\text { Insecticide + } \\
\text { (ha) }\end{array}$ & 454 & 197 & 55 & 33 & 0 & 0 & 0 \\
\hline $\begin{array}{l}\text { Sterile moth } \\
\text { releases } \\
\text { (millions) }\end{array}$ & 0 & 0 & 152.5 & 198.4 & 208.8 & 210.3 & 117.2 \\
\hline $\begin{array}{l}\text { Larvae } \\
\text { detected }\end{array}$ & 22 fields & 9 fields & 7 fields & 1 field & & & \\
\hline $\begin{array}{l}\text { Native moths } \\
\text { trapped }\end{array}$ & 1139586 & 159421 & 35771 & 1139 & 163 & 7 & 0 \\
\hline
\end{tabular}

In 2007 and 2008, sterile insect release was not available until 2009. The programme objectives were to drive populations down below conventional pest management field treatment thresholds. Northern Sonora's objectives were to treat all non- $B t$ cotton with PBW Rope on bamboo stakes. Limited conventional insecticide plus sprayable pheromone was required, but progressively reduced through 2010 (Table 15). Programme management treated fields with the highest risk with a second application of PBW Rope at 50-65 days, when triggered by native moth captures. Insecticide plus sprayable pheromone was used only when a larva was detected in boll samples.

In the first year (2007), with a full trap grid (1 trap per 4 ha non-Bt and 1 trap per 20 ha $B t$-cotton), captures totalled 1139586 native moths season-long. The San Luis Rio Colorado area contributed most of these captures. It was influenced by its adjacent neighbour, the Mexicali valley, which was not yet in the eradication programme. In 2008 captures declined significantly to 159421 (Table 15).

Perspective pre-programme data on file show season-long mean native moths per trap per week from 2006 through 2008 to be 106, 46, and 16. This downward progression continued to zero native moths captured in 2013. Solid evidence of 
reproduction is found when any larvae can be detected in a field. During the first year, 22 fields were positive, all in San Luis Río Colorado. By 2010, even with extensive "directed" sampling of fields with native moth captures, only in one field a larva was detected.

No PBW has been detected in this programmatic area after May of 2012. The last seven native moth captures coincide in time and space with the last adults captured in neighbouring Mexicali and Arizona.

\subsection{Mexicali, Baja California, Mexico (Phase IIIb)}

Ing. Enrique Montano, Gerente del Comité Estatal de Sanidad Vegetal, 2006-2007 Ing. Roberto Roche Uribe, Gerente del Comité Estatal de Sanidad Vegetal, 2008 to declaration.

The Mexicali Valley, during the course of this eradication programme, contained all the cotton in Baja California (Fig. 1). It was established as a production area in 1912. Its water source, like San Luis Río Colorado, is the Colorado River, its eastern border. The northern limit of this valley is the California, USA border with Mexico. As with San Luis Rio Colorado, if cotton were to be grown for its longest potential season, it would generate extremely high populations of PBW. Irrigation for cotton has long been terminated in late August. Yield potential is still high, with planting and harvest windows consistent with its Sonoran neighbour. This area has no PBW population separation from northern Sonora.

When PBW entered this system, as in San Luis Río Colorado, it drastically affected production practices. Insecticide use escalated for secondary pests as well as PBW. Shorter growing cycles became the reality. As in all areas, the introduction of $B t$-cotton was profound. Its use escalated even as growers ceased to find PBW resulting from eradication activities in non- $B t$ cotton (Table 16).

Pre-programme monitoring data for 2007 has been provided, indicating extremely high native moth captures. Programmatic control activities in non-Bt cotton started in 2008 with pheromone treatment of all fields. Two different high-rate systems were used in 2008. The PBW Rope was used on $73 \%$ of non- $B t$ fields. A second high-rate system was used on the remaining non- $B t$ fields.

In 2009-2012 all non- $B t$ fields were treated with the PBW Rope, targeting a pre-6 node cotton development window. After 2010, all PBW Rope applications at or before 6 leaf were applied on the bamboo stake. Dual insecticide-pheromone applications were used on fields in which trap captures exceeded one moth per trap per night, or in which larvae could be found. This occurred in 2008, from the week of 4 August through 15 September. Field re-treatment varied depending on trap captures. By 2011, only one field required treatment (36 ha, Table 16). Sterile moth releases started in 2009 with the majority directed over non-Bt fields. This continued through 2013 in areas where native moths were captured in 2012.

In population assessment, no larvae were detected after 2009. These data were from a programme evaluation survey of randomly selected non- $B t$ fields. Fields were selected when mapping of cotton fields was complete early in the season. Field selection occurred before boll set. 
Table 16. Mexicali valley, Baja California, Mexico pink bollworm eradication programme summary data

\begin{tabular}{|c|c|c|c|c|c|c|c|}
\hline Year & 2007 & 2008 & 2009 & 2010 & 2011 & 2012 & 2013 \\
\hline Total (ha) & 20643 & 19984 & 17385 & 20153 & 33671 & 32829 & 22814 \\
\hline$\% B t$-cotton & 62 & 68 & 78 & 84 & 96 & 96 & 96 \\
\hline $\begin{array}{l}\text { Pheromone } \\
\text { (ha) }\end{array}$ & 0 & 6505 & 3771 & 3170 & 1455 & 1511 & 0 \\
\hline $\begin{array}{l}\text { Insecticide+ } \\
\text { (ha) }\end{array}$ & 0 & 2750 & 1652 & 264 & 36 & 0 & 0 \\
\hline $\begin{array}{l}\text { Sterile moth } \\
\text { releases } \\
\text { (millions) }\end{array}$ & 0 & 0 & 822.6 & 766.3 & 825.5 & 755.4 & 258 \\
\hline $\begin{array}{l}\text { Larvae } \\
\text { detected } \\
(\%)\end{array}$ & $\begin{array}{r}1450 \\
(29)\end{array}$ & $\begin{array}{r}181 \\
(3.2)\end{array}$ & $\begin{array}{r}4 \\
(0.007)\end{array}$ & 0 & 0 & 0 & 0 \\
\hline $\begin{array}{l}\text { Native moths } \\
\text { trapped }\end{array}$ & 2705400 & 709203 & 162226 & 15258 & 401 & 18 & 0 \\
\hline
\end{tabular}

All native moth capture data in Table 16 were totals from the programmatic standard season-long trap grids. Pre-programme valley monitoring in 2007 produced a season-long moths/trap/week average of 103.9 native moths. Many of these delta traps were past trap capacity and no longer capturing all moths which entered the trap. At the end of the first year of programmatic treatments, season-long average capture/trap/week dropped to 9.2.

As was true in Sonora and Arizona, 2012 was the last year in which native adult moths were captured. In 2012, a total of 18 native moths were all captured on or before the week of 26 May. These were the last native moths captured and the last detection of any life form of PBW anywhere in this bi-national programme.

\section{CONCLUSIONS}

On November 22, 2012 ten municipalities in north-western Chihuahua were declared free of PBW (as officially eradicated). This area was the Ascensión work area which had not had a detected population for 5 years. Subsequently, on December 8, 2014, eradication was declared for the remainder of the state of Chihuahua. On February 3, 2016, PBW was declared eradicated from Sonora and Baja California (SENASICA 2018). 
Though not covered in this report, PBW has in the meantime also recently been eradicated from the Mexican states of Coahuila and Durango (Diario Oficial 2018). This latter cotton area (La Laguna) centres around the city of Torreón in the states of Coahuila and Durango, which was the first reported area infested with PBW in continental North America (Noble 1969). The state of Tamaulipas, which is contiguous to Texas and has likewise been involved in PBW eradication activities, also had no PBW captures in 2018, but has not yet been declared PBW-free (SADER 2018).

In the USA, eradication could only be declared after Bt-cotton labelling issues for refugia (grower variety selection) were resolved. This occurred after 6 years of continuous negative surveys. The United States Secretary of Agriculture signed the eradication proclamation for all USA cotton production areas on October 19, 2018 (USDA 2018). Eradication has been successfully achieved over a very diverse geographic and ecological range because many years of research and development had provided multiple surveillance and control tools (Noble 1969; Naranjo et al. 2002). These were tools which could be used synergistically. The area-wide integration of tools was then successfully tailored to varied habitats over the pest's broad range.

Resistance to $B t$-cotton is, in the view of the first author, the most important entomological issue concerning cotton worldwide. Movement of a multi-gene resistant $\mathrm{PBW}$ population back into this bi-national programme area would be of the gravest concern.

\section{ACKNOWLEDGEMENTS}

Dr. Michelle Walters passed away due to cancer before this manuscript could be completed. She worked extensively for PBW eradication throughout her career. Larry Antilla, Theodore N. Boratynski, Edwardo Gutierrez, Tish Bond, and Eoin B. Davis were invaluable in data verification and manuscript preparation.

It is not tenable within the scope of this paper to list all the people and organizations that were important for achieving success. In the USA, leaders from the producer community and "field" were the principal forces for initiation and execution. The project in Mexico followed the presidencies found in many of its state phytosanitary committees. Direct field managers for each state have already been listed in the text.

Important acknowledgments for Mexico agricultural authorities are: Dr. Jorge Hernandez Baeza, Director Sanidad Vegetal; Dr. Javier Trujillo Director, SENASICA; Ing. Hector Sanchez Anguiano, DGSV; and Ing. Juan Carlos RamirezSagahon, SENASICA.

In Chihuahua we worked with: Ing. Rubin Ortega Rodrigues, Ing. Lionel Gutierrez Estrada, Ing. Arnulfo Nunez Carbajal, Ing. Carlos Garcia Duran, Ing. Jesus Antonio Escarcega Terin, Ing. Izabel Roman Medina, Ing. Alfredo De La Torre Rivera (USDA FSN), Ing. Juan Angel Guzman M., Ing. Francisco Cardenas, Ing. Epifanio Hernandez G. Ing. Ricardo Alvarado Garcia, Ing. Luis Omar Jimenez Quintana, and Ing. Luis Carlos Ortega Duran. 
In Sonora programme colleges include: Ing. Gilberto Valdez, Ing. Urgujo, Ing. Erick Cortes Onofre, Ing. Mauricio Chavarria Onofre, Ing. Rene Yescas Dominguez, and Ing. Ricardo Vazquez.

Acknowledgements of importance for Baja California include: Ing. Enrique Montano, Ing. Roberto Roche Uribe, Ing. Hector Aguirre Romero, and Ing. Ricardo Mora Armento.

The USDA-APHIS-IS network collaborated with all the above and included: Elba Quintero, Nicholas Gutiérrez, Theodore Boratynski, Ing. Francisco Corrales Dorame (FSN), and Ing. Edwardo Gutiérrez (FSN).

In the USA the National Cotton Council provided the framework for all legislative, technical, managerial and budgetary decisions through its producer member Pink Bollworm Action Committee (PBWAC). Chairmen included Ted Pierce (Arizona), Bill Lovelady (Texas), Denis Palmer (Arizona), Clyde Sharp (Arizona), and Ted Sheely (California).

A Technical Advisory Subcommittee offered its recommendations. Vice President John Maguire and staff members Frank Carter and Don Parker are noted.

The most important contributions of the USDA-APHIS-PPD were in sterile insect production, regulatory issues and programmatic support. Fred D. Stewart, Ernie Miller, and Eoin Davis managed all rearing and shipping in sequence. The USDAAPHIS staff officers William J. Grefenstette, Osama A. El-Lissy, and James A. Schoenholz are noted.

El Paso, Texas producers that fostered the eradication programme were led by Bill Lovelady and Jim-Ed Miller. They worked with TBWF and its board of directors, the Foundation Director Lindy Patton and the Boll Weevil Programme Manager Osama El-Lissy. Woody Anderson provided primary grower leadership as Foundation Chairman.

The New Mexico cotton producers who were a constant throughout are represented by Keith Deputy and Robert Sloan. Work unit supervisors were Leighton Liesner and Allen Van Tassel.

Arizona's strength came from the Arizona Cotton Growers Association, Rick C. Lavis (Vice-President), and its operations arm, the producer-led Arizona Cotton Research and Protection Council. Council Chairmen include: Paul Ollerton, Clyde Sharp, Denis Palmer, Adam Hatley, and Jerry Rovey. Arizona directors previously listed and Mike Whitlow, Donna Fairchild, Mike Woodward, Bob Ellington, Penny Malone, Jerry Kerr, and Bobby Soto.

The California Cotton Pest Control Board (CCPCB) were primary funders of the 60 -year SIT containment programme and the PBW rearing facility. Wally Shropshire, Chairman, and Jack Stone were 50+ year influencers on this board. Funds were managed through CDFA with partnership with USDA.

Important early managers from CDFA included Dr. Isi Siddique and Robert Roberson. They were critical in administration of CCPCB funding and in construction of the rearing facility. Agricultural Commissioners in all California cotton production counties were the local regulatory arm. 


\section{REFERENCES}

Allen, C. T., L. E. Smith, S. E. Herrera, and L. W. Patton. 2005. Pink bollworm eradication in Texas a progress report, pp. 1219-1224. Proceedings Beltwide Cotton Conferences, New Orleans, Louisiana. National Cotton Council of America. Nashville, Tennessee, USA.

Allen, C. T. 2008. Boll weevil eradication: An areawide pest management effort, pp. 467-559. In O. Koul, G. Cuperus, and N. Elliott (eds.), Areawide pest management: Theory and implementation. CAB International. Wallingford, UK.

Anonymous. 1961. The pink bollworm in Arizona 1958-1960. USDA, Agricultural Research Service, Plant Protection Pest Control Division.

Antilla, L., and L. Liesner. 2008. Program advances in the eradication of the pink bollworm Pectinophora gossypiella in Arizona cotton, pp. 1162-1168. Proceedings Beltwide Cotton Conferences, Nashville, Tennessee. National Cotton Council of America. Nashville, Tennessee, USA.

Antilla, L., M. Whitlow, R.T. Staten, O. El-Lissy, and F. Meyers. 1996. An integrated approach in areawide pink bollworm management in Arizona, pp. 1083-1086. In P. Dugger, and D. A. Richter (eds.), Proceedings Beltwide Cotton Conferences, Memphis, Tennessee. National Cotton Council of America. Nashville, Tennessee, USA.

Antilla, L., M. Whitlow, B. Tabashnik, T. Dennehy, and Y. Carrière. 2001. Benefits of multi-level monitoring activities for a pink bollworm resistance management program in transgenic $(B t)$ cotton in Arizona, pp. 1173-1175. Proceedings Beltwide Cotton Conferences. National Cotton Council of America. Nashville, Tennessee, USA.

Baker, T. G., R. T. Staten, and H. M. Flint. 1990. Use of pink bollworm pheromone in the southwestern United States, pp 417-436. In R. L. Ridgway, R. M. Silverstein, and M. N. Inscoe (eds.), Behavior modifying chemicals for insect management: Application of pheromones and other attractants. Marcel Dekker, New York, USA.

Bierl, B. A., M. Beroza, R. T. Staten, P. E. Sonnet, and V. E. Adler. 1974. The pink bollworm sex attractant Journal of Economic Entomology 67: 211-216.

Brooks, T. W., C. C. Doane, and R. T. Staten. 1979. Experience with the first commercial pheromone communication disruptive for suppression of an agricultural pest, pp 375-388. In F. J. Ritter (ed.), Chemical ecology: Odour communication in animals. Elsevier/North-Holland Biomedical Press, Amsterdam, The Netherlands.

Burns, D. W., M. P. Murphy, M. L. Parsons, L. A. Hickle, and R. T. Staten. 1983a. The evaluation of internal elemental discriminators for pink bollworm by inductively coupled plasma-atomic emission spectrometry. Applied Spectroscopy 37: 120-123.

Burns, D. W., M. P. Murphy, K. L. Jones, M. L. Parsons, P. Farnsworth, E. T. Ozaki, and R. T. Staten. 1983b. The evaluation of internal elemental markers for Mediterranean fruit fly (Diptera: Tephritidae) reared in tagged artificial diets. Journal of Economic Entomology 76: 1397-1420.

Cardé, R. T., A. Mafra-Neto, R. T. Staten, and L. P. S. Kuenen. 1997. Understanding mating disruption in the pink bollworm. In P. Witzgall, and H. Arn (eds.), Technology transfer in mating disruption. Pheromones and other semiochemicals in integrated production. Proceedings IOBC-WPRS Symposium, 1996, Montpellier, France.

Dennehy, T. J., G. C. Unnithan, S. A. Brink, B. D. Wood, Y. Carrière, B. E. Tabashnik, L. Antilla, and M. Whitlow. 2004. Update on pink bollworm resistance to Bt cotton in the southwest, pp. 15691577. Proceedings Beltwide Cotton Conferences. National Cotton Council of America. Nashville, Tennessee, USA.

Diario Oficial. 2018. Acuerdo por el que se declara como zona libre del gusano rosado (Pectinophora gossypiella) a los estados de Coahuila de Zaragoza y Durango. Diario Oficial de la Federación, Primera Sección. 20 de diciembre de 2018. Secretaría de Agricultura y Desarrollo Rural (SADER). Estados Unidos Mexicanos. Ciudad de México, México.

El-Lissy, O., R. T. Staten, and B. Grefenstette. 2002. Pink bollworm eradication plan in the U.S, pp. 973-971. Proceedings Beltwide Cotton Conferences, Atlanta, Georgia. National Cotton Council of America. Nashville, Tennessee, USA.

Flint, H. M., S. Kuhn, B. Horn, and H. A. Sallam. 1974. Early season trapping of pink bollworm with gossyplure. Journal of Economic Entomology 67: 738-740.

Flint, H. M., J. R. Merkle, and A. Yamamoto. 1985. Pink bollworm (Lepidoptera Gelechiidae): Field testing a new polyethylene tube dispenser for gossyplure. Journal of Economic Entomology 78: 14311436. 
Flint, H. M., T. J. Henneberry, F. D. Wilson, E. Holguin, N. Parks, and R. E. Buehler. 1995. The effects of transgenic cotton Gossypium hirsutum lines containing Bacillus thuringiensis toxin genes for the control of the pink bollworm, Pectinophora gossypiella (Saunders) Lepidoptera Gelechiidae and other arthropods. The Southwestern Entomologist 20: 281-292.

Foster, R. N., R. T. Staten, and E. Miller. 1977. Evaluation of traps for pink bollworm. Journal of Economic Entomology 70: 289-291.

Friesen, J., and R. T. Staten. 2008. Progress report for the New Mexico pink bollworm, Pectinophora gossypiella (Saunders), eradication program, pp. 1179-1185. Proceedings Beltwide Cotton Conferences, Nashville, Tennessee. National Cotton Council of America. Nashville, Tennessee, USA.

Fye, R. E. 1976. Improved method for holding cotton bolls for detecting pink bollworm. U. S. Department of Agriculture, Agricultural Research Service Publication 1, ARS W 37, Western Region, 3 pp.

Graham, H. M., and C. L. Mangum. 1971. Larval diets containing dyes for tagging pink bollworm moths internally. Journal of Economic Entomology 64: 376-379.

Grefenstette, B., O. El-Lissy, and R. T. Staten. 2009. Pink bollworm eradication plan in the United States. U.S. Department of Agriculture, Animal and Plant Health Protection Service. Washington, DC, USA.

Head, G. P., and J. Greenplate. 2012. The design and implementation of insect resistance management programs for Bt crops. GM Crops \& Food: Biotechnology in Agriculture and the Food Chain 3: 144 153.

Hendrichs, J., M. J. B. Vreysen, W. R. Enkerlin, and J. P. Cayol. 2021. Strategic options in using sterile insects for area-wide integrated pest management, pp. 841-884. In V. A. Dyck, J. Hendrichs, and A. S. Robinson (eds.), Sterile Insect Technique - Principles and practice in Area-Wide Integrated Pest Management. Second Edition. CRC Press, Boca Raton, Florida, USA.

Hummel, H. E., L. K. Gaston, H. H. Shorey, R. S. Kaae, K. J. Byrne, and R. M. Silverstein. 1973. Clarification of the chemical status of the pink bollworm sex pheromone. Science 181: 873-875.

Knipling, E. F. 1971. Boll weevil and pink bollworm eradication: Progress and plans. Cotton Ginners Journal Yearbook 39: 23-30.

Leggett, J. E., O. El-Lissy, and L. Antilla. 1994. Pink bollworm moth catches with perimeter and in field gossyplure baited delta traps. The Southwestern Entomologist 19: 140-155.

Lingren, P. D., T. J. Henneberry, and T. W. Popham. 1989. Pink bollworm (Lepidoptera Gelechiidae): Nightly and seasonal activity patterns of male moths as measured in gossyplure-baited traps. Journal of Economic Entomology 82: 782-787.

Miller, E., F. Stewart, A. Lowe, and J. Bomberg. 1996. New method of processing diet for mass rearing pink bollworm, Pectinophora gossypiella (Saunders) (Lepidoptera: Gelechiidae). Journal of Agricultural Entomology 13: 129-137.

Naranjo, S. E., G. D. Butler, and T. J. Henneberry. 2002. A bibliography of the pink bollworm, Pectinophora gossypiella (Saunders). Bibliographies and Literature of Agriculture No. 136. USDA, Agricultural Research Service, USA. $156 \mathrm{pp}$.

Neal, C. R., and L. Antilla. 2001. Boll weevil establishment and eradication in Arizona and northwest Mexico pp. 213-224. In W. A. Dickerson, A. L. Brashear, J. T. Brumley, F. L. Carter, W. J. Grefenstette, and F. A. Harris (eds.), Boll weevil eradication in the United States through 1999. Reference Book Series No. 6. The Cotton Foundation Publisher, Memphis, Tennessee, USA.

Noble, L. W. 1969. Fifty years of research on the pink bollworm in the United States. U.S. Department of Agriculture, Agricultural Research Service, Agricultural Handbook No. 357.

Pierce, D. L., M. L. Walters, A. J. Patel, and S. P. Swanson. 1995. Flight path analysis of sterile pink bollworm release using GPS and GIS, pp. 1059-1060. In D. A. Richter, and J. Armour (eds.), Proceedings Beltwide Cotton Conferences, Memphis, Tennessee. National Cotton Council of America. Nashville, Tennessee, USA.

Pierce, J. B., C. Allen, W. Multer, T. Doederlein, M. Anderson, S. Russell, J. Pope, R. Zink, M. Walters, D. Kerns, J. Westbrook, and I. Smith. 2013. Pink bollworm (Lepidoptera: Gelechiidae) in the southern plains of Texas and New Mexico: Distribution and eradication of a remnant population. Southwestern Entomologist 38(3): 369-378.

Rudig, J. F., and D. F. Keaveny. 2008. Progress report and overview of pink bollworm, Pectinophora gossypiella (Saunders) eradication in California, pp. 1156-1192. Proceedings Beltwide Cotton Conferences. National Cotton Council of America. Nashville, Tennessee, USA.

(SADER) Secretaría de Agricultura y Desarrollo Rural. 2018. Sanidad Vegetal: Décimo segundo informe mensual campaña contra plagas reglamentadas del algodonero. Dirección General de Sanidad Vegetal, Dirección de Protección Fitosanitaria. Servicio Nacional de Sanidad, Inocuidada y Calidad Agroalimentaria (SENASICA), SADER, Gobierno de Mexico. 
Schmitt Jr., T. J. 1967. The pink bollworm in Arizona, second addendum. Agricultural Research Service, Plant Protection Pest Control Division, USDA, USA.

(SENASICA) Servicio Nacional de Sanidad, Inocuidad y Calidad Agroalimentaria. 2018. Declara SAGARPA Zona Libre del gusano rosado del algodonero a tres estados y un municipio de Coahuila. Chihuahua, Baja California y Sonora, así como el municipio de Sierra Mojada en Coahuila obtuvieron el estatus libre de plaga. 7 de noviembre de 2018. Secretaría de Agricultura, Ganadería, Desarrollo Rural, Pesca y Alimentación. Ciudad de Mexico, Mexico.

Shahid, J. 2014. Bollworms develop resistance against $B t$ cotton crop. Islamabad: Farmers and agriculture scientists are alarmed by the destructive attack of bollworms this year that seem to have developed resistance against the genetically-modified (GM) cotton crop. Dawn, July 14, 2014. Islamabad, Pakistan.

Staten, R. T., and J. C. Ramirez-Sagahon. 2008. The bi-national pink bollworm eradication program an overview, pp. 1169-1178. Proceedings Beltwide Cotton Conference, Nashville, Tennessee. National Cotton Council of America. Nashville, Tennessee, USA.

Staten, R. T., R. W. Rosander, and D. F. Keaveny. 1993. Genetic control of cotton insects: The pink bollworm as a working program, pp. 269-283. In Management of insect pests: Nuclear and related molecular and genetic techniques. International Atomic Energy Agency, Vienna, Austria.

Staten, R. T., L. Antilla, and M. L. Walters. 1995. Pink bollworm management: Prospects for the future, pp. 153-156. In D. A. Richter, and J. Armour (eds.), Proceedings Beltwide Cotton Conferences, Memphis, Tennessee. National Cotton Council of America. Nashville, Tennessee, USA.

Staten, R. T., O. El-Lissy, and L. Antilla. 1997. Successful area-wide program to control pink bollworm by mating disruption, pp. 383-396. In R. Cardé, and A. K. Minks (eds.), Insect pheromone research: New directions. Chapman Hall, New York, USA.

Staten R. T., M. Walters, R. Roberson, and S. Birdsall. 1999. Area-wide management / maximum suppression of pink bollworm in Southern California, pp. 985-988. Proceedings Beltwide Cotton Conferences, Memphis, Tennessee. National Cotton Council of America. Nashville, Tennessee, USA.

Staten, R. T., E. Miller, M. Grunnet, P. Gardner, and E. Andress. 1988. The use of pheromones for pink bollworm management in western cotton, pp. 206-209. In J. M. Brown, and D. A. Richter (eds.), Proceeding Beltwide Cotton Conferences, Memphis, Tennessee. National Cotton Council of America. New Orleans, Louisiana, USA.

Staten, R. T., H. M. Flint, R. C. Weddle, E. Quintero, R. E. Zarate, C. M. Finnell, M. Hernández, and A. Yamamoto 1987. Pink bollworm (Lepidoptera Gelechiidae): Large scale field trials with a high rate gossyplure formulation. Journal of Economic Entomology 80: 1207-1271.

Stern, V. M. 1979. Long- and short-range dispersal of the pink bollworm Pectinophora gossypiella over southern California. Environmental Entomology 8: 524-527.

Stern, V. M., and V. Sevacherian. 1978. Long-range dispersal of pink bollworm into the San Joaquin Valley. California Agriculture 32(7): 4-5.

Stern, V. M., R. F. Smith, R. van der Bosch, and K. S. Hagen. 1959. The integration of chemical and biological control of the spotted alfalfa aphid: The integrated control concept. Hilgardia 29(2): 81-154.

Suckling, D. M., L. Stringer, A. Stephens, B. Woods, D. Williams, G. Baker, and A. El-Sayed. 2014. From integrated pest management to integrated pest eradication: Technologies and future needs. Pest Management Science 70: 179-189.

Tabashnik, B. E., T. Brevault, and Y. Carriere. 2013. Insect resistance to Bt crops: Lessons from the first billion acres. Nature Biotechnology 31: 510-521.

Tabashnik, B. E., A. L. Patin, T. J. Dennehy, Y. B. Liu, Y. Carrière, M. A. Sims, and L. Antilla. 2000. Frequency of resistance to Bacillus thuringiensis in field populations of pink bollworm. Proceedings National Academy of Sciences USA 97(24): 12980-12984.

Tabashnik, B. E., M. S. Sisterson, P. C. Ellsworth, T. J. Dennehy, L. Antilla, L. Liesner, M. Whitlow, R. T. Staten, J. A. Fabrick, G. C. Unnithan, A. J. Yelich, C. Ellers-Kirk, V. S. Harpold, X. Li, and Y. Carriere. 2010. Suppressing resistance to $B t$ cotton with sterile insect release. Nature Biotechnology 28: 1304-1307.

(TBWEF) Texas Boll Weevil Eradication Foundation. 2019.

(USDA) United States Department of Agriculture. 2018. USDA announces pink bollworm eradication significantly saving cotton farmers in yearly control costs. Press Release No. 0222.18. October 19, 2018. Washington, DC, USA.

Vreysen, M. J. B., A. S. Robinson, and J. Hendrichs (eds.). 2007. Area-wide control of insect pests: From research to field implementation. Springer. Dordrecht, The Netherlands. 789 pp. 
Walters, M., R. T. Staten, and R. C. Roberson. 1988. Pink bollworm integrated management technology under field trial conditions in the Imperial Valley, California, pp. 1282-1285. In P. Dugger, and D. A. Richter (eds.), Proceedings Beltwide Cotton Conferences, Memphis, Tennessee. National Cotton Council of America. Nashville, Tennessee, USA.

Walters, M., Staten, R. Sequeira, and T. Dennehy. 1999. Preliminary analysis of pink bollworm population distributions in a large acreage of genetically engineered cotton with regard to resistance management, pp. 989-991. In P. Dugger, and D. A. Richter (eds.), Proceedings Beltwide Cotton Conferences, Memphis, Tennessee. National Cotton Council of America. Nashville, Tennessee, USA.

Walters, M. L., R. T. Staten, and R. C. Roberson. 2000. Pink boll worm integrated management using sterile insects under field trial conditions, Imperial Valley, California, pp. 201-206. In K.-H. Tan (ed.), Area-wide control of fruit flies and other insect pests. Penerbit Universiti Sains Malaysia, Pulau Pinang, Malaysia.

Wan, P., D. Xu, S. Cong, Y. Jiang, Y. Huang, J. Wang, H. Wu, L. Wang, K. Wu, Y. Carriere, A. Mathias, X. Li, and B. E. Tabashnik. 2017. Hybridizing transgenic Bt cotton with non- $B t$ cotton counters resistance to pink bollworm. Proceedings National Academy of Sciences USA 114(21): 5413 5418.

Watson, T. F. 1995. Impact of transgenic cotton on pink bollworm and other Lepidopteran insects, pp. 784-796. In D. A. Richter, and J. Armour (eds.), Proceedings Beltwide Cotton Conferences, Memphis, Tennessee. National Cotton Council of America. Nashville, Tennessee, USA.

Wilson, R. D., H. M. Flint, W. R. Deaton, D. A. Fischhoff, F. J. Perlak, T. A. Armstrong, R. L. Fuchs, S. A. Berberich, N. J. Parks, and B. R. Stapp 1992. Resistance of cotton lines containing a Bacillus thuringiensis toxin to pink bollworm (Lepidoptera: Gelechiidae) and other insects. Journal of Economic Entomology 85: 1516-1521. 